\title{
AVALIAÇÃO DE RECIPIENTES E SUBSTRATOS PARA A PRODUÇÃO DE MUDAS DE QUIABEIRO \\ (Abelmoschus esculentus (L.) Moench)
}

\section{VALÉRIA APARECIDA MODOLO}

Engenheiro Agrônomo

Orientador: Prof. Dr. JOÃO TESSARIOLI NETO

Dissertação apresentada à Escola Superior de Agricultura "Luiz de Queiroz", Universidade de São Paulo, para a obtenção do título de Mestre em Agronomia, Área de Concentração: Fitotecnia.

\author{
PIRACICABA \\ Estado de São Paulo - Brasil \\ Janeiro - 1998
}


Dados Internacionais de Catalogação na Publicação (CIP)

DIVISÃO DE BIBLIOTECA E DOCUMENTAÇÃO - Campus "Luiz de Queiroz"/USP

Modolo, Valéria Aparecida

Avaliação de recipientes e substratos para a produção de mudas de quiabeiro

(Abelmoschus esculentus (L.) Moench) / Valéria Aparecida Modolo. - Piracicaba, 1998.

$53 \mathrm{p}$.

Dissertação (mestrado) - Escola Superior de Agricultura Luiz de Queiroz, 1998. Bibliografia.

1. Muda de quiabo 2. Produção I. Título 


\section{AVALIAÇÃO DE RECIPIENTES E SUBSTRATOS PARA \\ A PRODUÇÃO DE MUDAS DE QUIABEIRO}

(Abelmoschus esculentus (L.) Moench)

VALÉRIA APARECIDA MODOLO

Aprovada em: 11.03.1998

Comissão julgadora:

Prof. Dr. João Tessarioli Neto

ESALQ/USP

Prof. Dr. Keigo Minami ESALQ/USP

Dr. Francisco Antonio Passos IAC

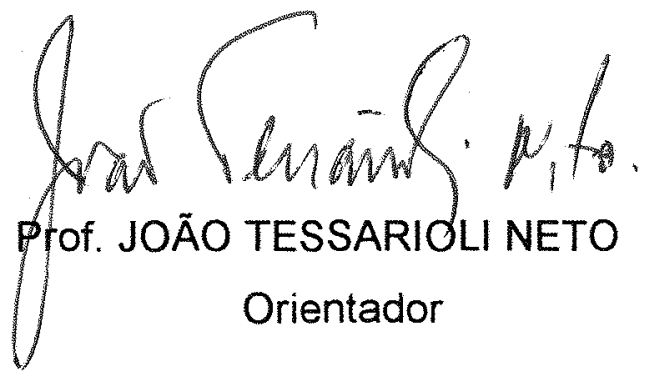


Aos meus pais, Narcizo e Yvonne, por todo carinho, amor e compreensão ao longo de toda minha vida.

\section{Ofereço.}

Aos meus irmãos, Bel e Júnior, e cunhados, Luís e Inês, pelo apoio, amizade e solidariedade durante todos os momentos. Às minhas crianças, queridos sobrinhos Thiago, Matheus e Victória, pela alegria de suas existências. 


\section{AGRADECIMENTOS}

À Deus, por sempre indicar os melhores caminhos na minha vida.

Ao Prof. João Tessariolli Neto, pela orientação e prestativos ensinamentos durante os momentos necessários.

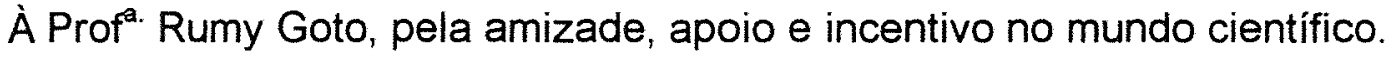

Ao Prof. Salim Simão, por suas valiosas dicas durante o curso.

Ao Prof. Keigo Minami pelas importantes sugestões.

Ao Departamento de Horticultura, professores e funcionários, especialmente à $D^{\text {na. }}$ Helena e à Célia, pelo carinho e amizade.

Ao Prof. Ricardo Ferraz, pela colaboração e empréstimo de equipamentos e ao Prof. Carlos Tadeu dos Santos Dias, pelo auxílio na análise estatística dos dados.

Aos amigos Luis Enrique Robledo, Walter Rodriguez, Inácio de Barros e Shoey Kanashiro, pelo companheirismo e paciência no decorrer do curso e, principalmente, durante os intermináveis dias de avaliação de experimento.

Aos amigos Gilson Rezende (§), Ricardo Kluge, Paulo Araújo, Nilton Medeiros Costa e Angelo Jacomino, pela troca de idéias, discussões sobre temas profissionais e pessoais que muito auxiliaram na minha formação.

Às amigas Tamara Maria Gomes, Luciana Augusto Barrichello, Maria Alice Chiozzo, Regma Caetano e Adriana Luzia Pontes, por sentir tão sincera amizade.

Ao querido Juan, pelo carinho e paciência durante a fase conclusiva deste trabalho.

À Capes, pela concessão da bolsa de estudos. 


\section{SUMÁRIO}

Página

LISTA DE FIGURAS..................................................................... vii

LISTA DE TABELAS ..................................................................... viii

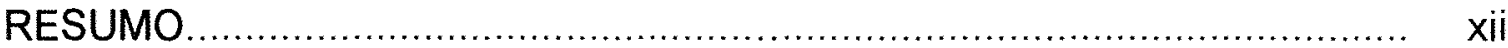

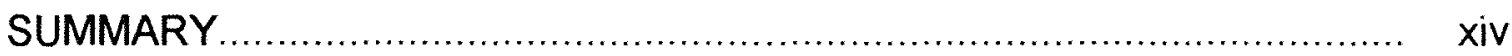

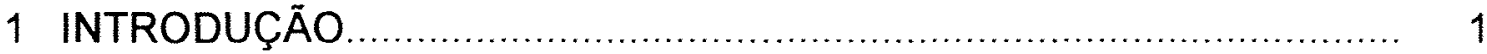

2 REVISÃO DE LITERATURA ...................................................... 3

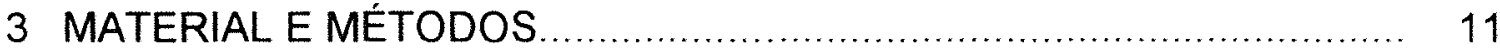

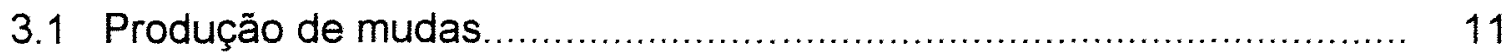

3.1.1 Caracterização do local...................................................... 11

3.1.2 Tratamentos adotados .......................................................... 13

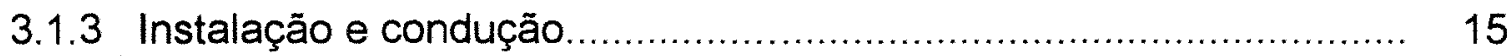

3.1.4 Delineamento experimental................................................ 16

3.1.5 Parâmetros estimados............................................................. 17

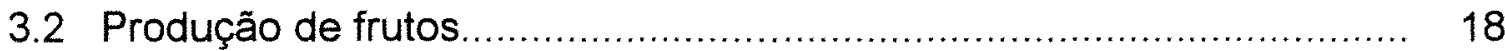

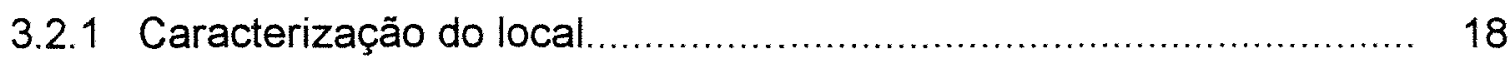

3.2.2 Instalação da cultura ............................................................... 19

3.2.3 Delineamento experimental.................................................. 20

3.2.4 Parâmetros estimados............................................................... 20

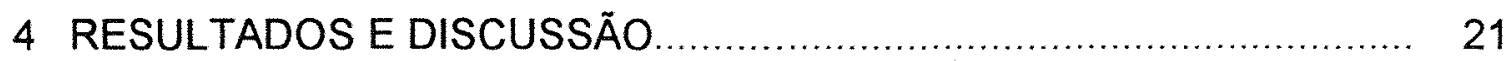

4.1 Resultados da avaliação das mudas ................................................ 21

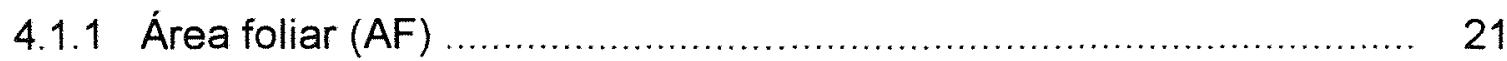

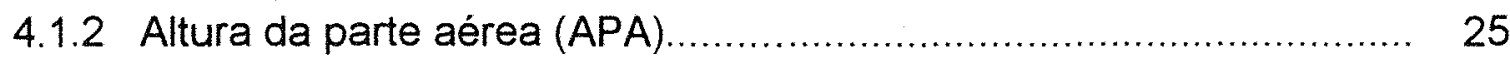

4.1.3 Diâmetro da parte mediana do caule (DC) ................................... 28

4.1.4 Peso da matéria seca da parte aérea (PMSA) ........................... 32

4.1.5 Peso da matéria seca do sistema radicular (PMSR) ...................... 35

4.2 Discussão dos resultados da produção de mudas .............................. 39

4.3 Resultados obtidos para a avaliação da produção de frutos ............... 43 
4.3.1 Produção em número de frutos ............................................. 43

4.3.2 Produção em peso de frutos .................................................... 44

4.4 Discussão dos resultados obtidos no campo .................................... 45

4.5 Considerações gerais................................................................. 46

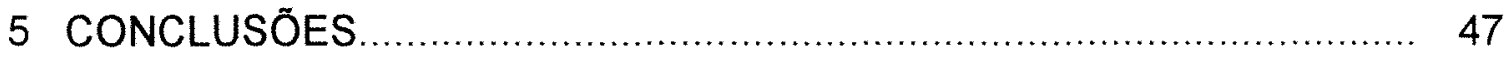

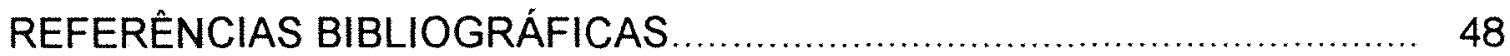




\section{LISTA DE FIGURAS}

Página

1 Médias de área foliar (AF), de acordo com os tratamentos, nas cinco épocas de avaliação...................................................... 40

2 Médias de altura da parte aérea (APA), de acordo com os tratamentos, nas cinco épocas de avaliação

3 Médias de peso da matéria seca da parte aérea (PMSA), de acordo com os tratamentos, nas cinco épocas de avaliação.

4 Médias de peso da matéria seca do sistema radicular (PMSR), de acordo com os tratamentos, nas cinco épocas de avaliação. 


\section{LISTA DE TABELAS}

Página

1 Dados meteorológicos no período 1917-1996 (Estação Agrometeorológica da Esalq/USP, Dpto. de Física e Meteorologia. Piracicaba - SP), 1997

2 Dados meteorológicos durante o período experimental, no município de Piracicaba-SP. (Estação Agrometeorológica da Esalq/USP, Dpto. de Física e Meteorologia. Piracicaba - SP), 1997

3 Caracterização das bandejas utilizadas

4 Caracterização dos substratos utilizados.....

5 Esquema de análise de variância para as causas de variação........

6 Resultado da análise de solo da área experimental. (Setor de Nutrição Mineral de Plantas, Dpto. de Química da Esalq/USP, Piracicaba - SP).

7 Resultado da análise de solo (micronutrientes, em ppm) da área experimental. (Setor de Nutrição Mineral de Plantas, Dpto. de Química da Esalq/USP, Piracicaba - SP).

8 Médias obtidas, em $\mathrm{cm}^{2}$, para área foliar (AF) das mudas de quiabeiro produzidas nos diferentes tipos de bandejas $e$ substratos, referentes à primeira avaliação

9 Médias obtidas, em $\mathrm{cm}^{2}$, para área foliar (AF) das mudas de quiabeiro produzidas nos diferentes tipos de bandejas $e$ substratos, referentes à segunda avaliação.

10 Médias obtidas, em $\mathrm{cm}^{2}$, para área foliar (AF) das mudas de quiabeiro produzidas nos diferentes tipos de bandejas $e$ substratos, referentes à terceira avaliação. 
11 Médias obtidas, em $\mathrm{cm}^{2}$, para área foliar (AF) das mudas de quiabeiro produzidas nos diferentes tipos de bandejas e substratos, referentes à quarta avaliação.

12 Médias obtidas, em $\mathrm{cm}^{2}$, para área foliar (AF) das mudas de quiabeiro produzidas nos diferentes tipos de bandejas e substratos, referentes à quinta avaliação.

13 Médias obtidas, em cm, para altura da parte aérea (APA) das mudas de quiabeiro produzidas nos diferentes tipos de bandejas e substratos, referentes à primeira avaliação.

14 Médias obtidas, em cm, para altura da parte aérea (APA) das mudas de quiabeiro produzidas nos diferentes tipos de bandejas e substratos, referentes à segunda avaliação.

15 Médias obtidas, em cm, para altura da parte aérea (APA) das mudas de quiabeiro produzidas nos diferentes tipos de bandejas e substratos, referentes à terceira avaliação.

16 Médias obtidas, em $\mathrm{cm}$, para altura da parte aérea (APA) das mudas de quiabeiro produzidas nos diferentes tipos de bandejas e substratos, referentes à quarta avaliação.

17 Médias obtidas, em $\mathrm{cm}$, para altura da parte aérea (APA) das mudas de quiabeiro produzidas nos diferentes tipos de bandejas e substratos, referentes à quinta avaliação.

18 Médias obtidas, em mm, para diâmetro da parte mediana do caule (DC) das mudas de quiabeiro produzidas nos diferentes tipos de bandejas e substratos, referentes à primeira avaliação.

19 Médias obtidas, em mm, para diâmetro da parte mediana do caule (DC) das mudas de quiabeiro produzidas nos diferentes tipos de bandejas e substratos, referentes à segunda avaliação.

20 Médias obtidas, em $\mathrm{mm}$, para diâmetro da parte mediana do caule (DC) das mudas de quiabeiro produzidas nos diferentes tipos de bandejas e substratos, referentes à terceira avaliação. 
21 Médias obtidas, em mm, para diâmetro da parte mediana do caule (DC) das mudas de quiabeiro produzidas nos diferentes tipos de bandejas e substratos, referentes à quarta avaliação.......................

22 Médias obtidas, em mm, para diâmetro da parte mediana do caule (DC) das mudas de quiabeiro produzidas nos diferentes tipos de bandejas e substratos, referentes à quinta avaliação

23 Médias obtidas, em g, para peso da matéria seca da parte aérea (PMSA) das mudas de quiabeiro produzidas nos diferentes tipos de bandejas e substratos, referentes à primeira avaliação.

24 Médias obtidas, em g, para peso da matéria seca da parte aérea (PMSA) das mudas de quiabeiro produzidas nos diferentes tipos de bandejas e substratos, referentes à primeira avaliação

25 Médias obtidas, em g, para peso da matéria seca da parte aérea (PMSA) das mudas de quiabeiro produzidas nos diferentes tipos de bandejas e substratos, referentes à primeira avaliação

26 Médias obtidas, em g, para peso da matéria seca da parte aérea (PMSA) das mudas de quiabeiro produzidas nos diferentes tipos de bandejas e substratos, referentes à primeira avaliação.

27 Médias obtidas, em g, para peso da matéria seca da parte aérea (PMSA) das mudas de quiabeiro produzidas nos diferentes tipos de bandejas e substratos, referentes à primeira avaliação.

28 Médias obtidas, em g, para peso da matéria seca do sistema radicular (PMSR) das mudas de quiabeiro produzidas nos diferentes tipos de bandejas e substratos, referentes à primeira avaliação.

29 Médias obtidas, em $\mathrm{g}$, para peso da matéria seca do sistema radicular (PMSR) das mudas de quiabeiro produzidas nos diferentes tipos de bandejas e substratos, referentes à segunda avaliação. 
30 Médias obtidas, em g, para peso da matéria seca do sistema radicular (PMSR) das mudas de quiabeiro produzidas nos diferentes tipos de bandejas e substratos, referentes à terceira avaliação.

31 Médias obtidas, em g, para peso da matéria seca do sistema radicular (PMSR) das mudas de quiabeiro produzidas nos diferentes tipos de bandejas e substratos, referentes à quarta avaliação.

32 Médias obtidas, em g, para peso da matéria seca do sistema radicular (PMSR) das mudas de quiabeiro produzidas nos diferentes tipos de bandejas e substratos, referentes à quinta avaliação.

33 Número de frutos produzidos de plantas de quiabeiro, referentes às mudas obtidas nos diferentes tipos de bandejas e substratos.....

34 Produção de frutos, em gramas, das plantas de quiabeiro referentes as mudas obtidas nos diferentes tipos de bandejas e substratos. 


\section{AVALIAÇÃO DE RECIPIENTES E SUBSTRATOS \\ PARA A PRODUÇÃO DE MUDAS DE QUIABEIRO}

(Abelmoschus esculentus (L.) Moench)

Autora: VALÉRIA APARECIDA MODOLO Orientador: Prof. Dr. JOÃO TESSARIOLI NETO

\section{RESUMO}

Com o objetivo de avaliar o desenvolvimento de mudas de quiabeiro, cultivar Santa Cruz - 47, produzidas no sistema de bandejas de isopor, realizou-se o presente trabalho no Campo Experimental do Departamento de Horticultura da Escola Superior de Agricultura "Luiz de Queiroz". O experimento constou de duas etapas: produção das mudas e transplante destas mudas em campo, para avaliação da produção comercial de frutos. Para a produção de mudas, que ocorreu em ambiente protegido, foram utilizados 3 tipos de bandejas, que diferem entre si pelo volume e altura das células, associadas a quatro diferentes substratos. Os substratos constaram de variações de uma mistura comercial denominada GII, produzida pela Empresa Gioplanta. O delineamento experimental foi de blocos inteiramente casualizados, com 4 repetições, no esquema fatorial de $3 \times 4$, sendo um dos fatores os tipos de bandejas e o outro, os substratos. $O$ desenvolvimento das mudas foi avaliado aos 12, 17, 22, 27 e 32 dias à partir da semeadura, estimando-se os seguintes parâmetros: área foliar, altura da parte aérea, diâmetro da parte mediana do caule, peso da matéria seca do sistema radicular e peso da matéria seca da parte aérea. Para avaliação da produção comercial de frutos, foram 
transplantadas no campo 30 mudas de cada um dos doze tratamentos, sendo que, cada parcela experimental constou de 5 fileiras de $3,0 \mathrm{~m}$ de comprimento, totalizando uma área de $15 \mathrm{~m}^{2}$. O delineamento experimental foi o mesmo utilizado na produção de mudas. A colheita iniciou-se aos 49 dias após o transplante das mudas para o campo, sendo que foram colhidos os frutos no tamanho comercial, das 12 plantas centrais. Nesta etapa foram avaliados número e peso total de frutos. Para as condições do experimento, concluiu-se que as bandejas de maior volume proporcionaram melhor desenvolvimento das mudas para todos os parâmetros estudados. No substrato que recebeu casca de arroz carbonizado na proporção 1:1, observou-se menor desenvolvimento das mudas. A utilização do produto comercial (adubado) com suplementação de nutrientes, favoreceu o desenvolvimento das mudas de quiabeiro. Para a produção de frutos, observou-se maior produtividade em plantas originadas de mudas provenientes das bandejas de maior volume (T1 e T2), independentemente do substrato utilizado. A menor produtividade foi obtida quando foi adicionada casca de arroz carbonizado na proporção $1: 1$, ao produto comercial GII, independentemente da bandeja utilizada. 


\title{
EVALUATION OF OKRA (Abelmoschus esculentus (L.) Moench) SEEDLINGS IN DIFFERENT SUBSTRATES AND CONTAINERS
}

\author{
Author: VALÉRIA APARECIDA MODOLO \\ Adviser: Prof. Dr. JOÃO TESSARIOLI NETO
}

\section{SUMMARY}

An experiment with three types of trays and four different substrates was carried out in a greenhouse at the Horticulture Department of Escola Superior de Agricultura "Luiz de Queiroz" - Universidade de São Paulo - ESALQ-USP. The experiment had two parts: seedling production and fruit production. Trays with different cell size were used in the okra seedling production. The substrates used were a blend of a commercial mixture made by Empresa Gioplanta. The experimental design was a completely randomized block, with 3 $\times 4$ factorial arrangement. One of the factors was represented by 3 types of trays, and the other by different substrates. The evaluation for the growing analisys was done 12,17, 22, 27 and 32 days after germination. The following criteria was used to evaluate the development of the seedlings: leaf area; diameter of the medium stem; height of the stem; dry weight of the root, leaf and stem. In the field were transplanted 30 seedlings to evaluate fruits production. The experimental design was the same used in the first part. Commercial size fruits were harvested from the 12 central plants 49 days after seedling transplant. In this part fruit weigh and number were evaluated. The results indicated that the production of okra seedlings in trays with largest cell volume presented the best results for all the parameters studied. Trays of various types that contained substrate GII and carbonized rice hulls in the proportion 1:1, 
presented less developed seedlings. Initial fertilizing and fertilizing during seedling growth permitted a better development of okra seedlings. In the field the plants grown in largest cell volume produced more fruits than plants from small cell volume, regardless the substrate. The lowest produtivity was obtained when GII and carbonized rice hulls were mixed (1:1) in the seedling production, independently of the tray used. 


\section{INTRODUÇÃo}

A cultura do quiabeiro (Abelmoschus esculentus (L.) Moench) é bastante popular entre os povos dos trópicos, pois além de ser considerada uma hortaliça rústica, apresenta certa tolerância ao calor, condição climática presente nesta parte do globo.

A capacidade de produção da cultura é alta e apesar do consumo brasileiro se restringir ao fruto, existe a possibilidade da extração de óleo à partir das sementes ou até da utilização das folhas como forragem na alimentação animal.

Um dos principais problemas da cultura, que faz com que a população final de plantas no campo seja variável, diminuindo a produtividade, é a germinação das sementes. O quiabeiro possui sementes chamadas "duras", caracterizadas por apresentarem uma camada impermeável à água e ao oxigênio necessários para a germinação. Isto faz com que sejam semeadas grandes quantidades de sementes e posteriormente, após a emergência das plântulas, haja necessidade de ser realizado desbaste, o que encarece o processo produtivo, gera um "stand" desuniforme e diminui a produtividade.

A produção de mudas se apresenta como uma alternativa quando se sabe que as sementes de uma determinada espécie ou variedade apresentam determinados problemas e necessitam de um maior cuidado na fase de germinação e emergência.

Dentre os sistemas de produção de mudas, o sistema de produção através de bandejas de isopor tem se mostrado eficiente sob diversos aspectos. Neste sistema, devido aos cuidados oferecidos na fase inicial da 
planta, na maioria das vezes tem-se uma semente originando uma planta, otimizando assim o uso das sementes.

$\mathrm{Na}$ cultura do quiabo, além deste benefício, a produção de mudas oferece a possibilidade da antecipação do plantio, pois a necessidade de temperaturas mais elevadas para a germinação restringe, em algumas regiöes do país, ao cultivo em somente determinadas épocas do ano. Sendo assim, este sistema propicia a preparação das mudas em uma época onde as condições climáticas não são tão favoráveis à germinação das sementes, devido a produção de mudas ocorrer em ambiente protegido.

A produção de mudas no sistema de bandejas viabilizou a produção e a comercialização de mudas em larga escala e atualmente, já vem sendo empregada em várias espécies olerícolas como alface, tomate e pimentão. Entretanto, estudos sobre a sua viabilidade em outras culturas ainda precisam ser realizados.

No mercado há diversos modelos de bandejas com diferentes números de células individuais; profundidades e volumes diversos; formatos variáveis, podendo ser redondas, piramidais, cilíndricas e com possibilidade de reutilização. Assim também, existem substratos comerciais à base de vermiculita e casca de pinus, elaborados por diferentes firmas especializadas e recomendados para algumas culturas.

Sendo assim, o objetivo deste trabalho foi avaliar o desenvolvimento de mudas de quiabeiro produzidas em três tipos de bandejas de isopor de formato piramidal e distintas quanto ao volume, bem como em três variações de um substrato comercial. Também foi objetivo a avaliação da produção comercial de frutos no campo para os diferentes tipos de mudas formadas. 


\section{REVISÃO DE LITERATURA}

A espécie Abelmoschus esculentus (L.) Moench é uma das mais antigas, sendo já cultivada pelos egípcios e vários povos da antiguidade. A cultura ainda é cultivada em regiões tropicais e subtropicais de baixas altitudes da Ásia, África e América, com extensão às regiões temperadas da bacia Mediterrânea (Charrier, 1984).

Esta hortaliça se situa entre as plantas hortícolas de alto valor alimentício, ciclo vegetativo rápido, fácil cultivo e alta rentabilidade (Costa et al., 1981) e devido às suas utilidades, tem sofrido um crescente aumento de consumo, tanto in natura como na forma de conserva (Pedrosa et al., 1983).

No Brasil, de uma maneira geral, a cultura vem sendo cultivada principalmente no Rio de Janeiro, destacando-se a região metropolitana da capital e a Baixada Litorânea (Martinello et al., 1996).

No início da década de 90 a área plantada no país era de 3.400 ha, com uma produção de 48.200 toneladas. O estado de São Paulo participava com 621 ha desse total, colaborando com 13,5 \% da produção brasileira (Camargo Filho \& Mazzei, 1994). Atualmente a área plantada no estado aumentou bastante, alcançando 1.575 ha no ano de 1995 , sendo que a região de Araçatuba contribui com a maior parte desta área $(62,8 \%)$, seguida de Campinas (11,8\%), Franca e São José do Rio Preto em menor escala (Instituto de Economia Agrícola e Coordenadoria de Assistência Técnica Integral, 1996).

Os usos e aplicações dos frutos do quiabeiro são bastantes diversificados, estando sua maior utilização na alimentação humana. Este vegetal é uma importante fonte de vitaminas e sais minerais, incluindo o cálcio, 
os quais são frequentemente carentes na dieta dos países em desenvolvimento (Hamon et al., 1990). Segundo Bernardi (1957), $100 \mathrm{~g}$ do produto (5 a 10 frutos no ponto de consumo) contém $90 \%$ de água; 39 calorias; $2 \mathrm{~g}$ de proteínas; $6 \mathrm{~g}$ de carboidratos; $53 \mathrm{mg}$ de fósforo; $0,6 \mathrm{mg}$ de ferro; $0,12 \mathrm{~g}$ de tiamina e $30 \mathrm{~g}$ de ácido ascórbico. Quanto ao teor vitamínico, Pimentel (1985) refere-se a presença de 850 U.I. de pró-vitamina A; $130 \mathrm{mcg}$ de B1; $75 \mathrm{mcg}$ de B2; 0,70 mg de B5 e 25,8 mg de vitamina C. Embora este teor de vitamina C seja alto no fruto jovem, após a colheita ele desaparece rapidamente, mesmo em temperatura ambiente.

Como hortaliça, forma predominantemente consumida no Brasil, somente o fruto é consumido (Minami et al., 1997). Os frutos do quiabeiro são mucilaginosos, do tipo cápsula e devem ser consumidos antes que concluam seu desenvolvimento. Segundo Coelho et al. (1974), à medida que os frutos se desenvolvem, aumenta o teor de fibras nos mesmos até atingirem determinado limite que os tornam impróprios para consumo. Assim, o estágio de consumo está relacionado com a redução inicial do teor de matéria seca, pois a fibra que se desenvolve nos frutos à medida que ele amadurece pode depreciar a sua qualidade.

Os frutos do quiabeiro podem ser armazenados por 7 a 10 dias em temperaturas entre 7 e $10{ }^{\circ} \mathrm{C}$ e 90 e $95 \%$ de umidade relativa, segundo Handerburg et al. (1986). Já Pantástico (1975) cita que o armazenamento pode durar até duas semanas em temperatura e umidade relativa de $8,9^{\circ} \mathrm{C}$ e $90 \%$, respectivamente, desde que sejam colhidos frutos de elevada qualidade.

Para o consumo o ano todo, os frutos podem também ser conservados na forma de fatias secas naturalmente ao sol, como é feito na África e na Índia, ou congelados ou esterilizados, forma predominante nos Estados Unidos (Martinello, 1995).

Em alguns paises da África e da Ásia as folhas são utilizadas como forragem na alimentação animal e em determinadas regiões da Arábia, desde há muito tempo, faz-se uma bebida das sementes torradas, usada em 
substituição ao café (Gurgel \& Mitidieri, 1954). Existem também citações de aplicação medicinal, onde pode-se usar o cataplasma de folhas cozidas, no caso de pneumonias e bronquites (Pimentel, 1985), ou a cocção de frutos novos, como expectorante ou contra certas doenças do aparelho urinário (Gurgel \& Mitidieri, 1954).

Para fins industriais, existe interesse na cultura do quiabeiro, especialmente no setor têxtil, pois as fibras produzidas pelas hastes ou caules das plantas apresentam boa qualidade de resistência à distensão e elasticidade. Além disso, existe a possibilidade de se extrair óleo comestivel das sementes, o que ocorre principalmente nos paises desenvolvidos (Pedrosa, 1976). O óleo produzido é semelhante ao de algodão e, quando comparado ao de soja observa-se um maior teor de $\alpha$-tocofenol, produto responsável pela estabilidade do óleo (Minami et al., 1997).

Embora seja uma cultura promissora tanto do ponto de vista olerícola como do industrial, poucas técnicas têm sido estudadas para melhoria das condições de cultivo. A produtividade média paulista, segundo o Instituto de Economia Agrícola e Coordenadoria de Assistência Técnica Integral (1996), é de aproximadamente 12 tha, mas trabalhos realizados em outros países mostram que com alto nível de tecnologia a cultura tem potencialidade de chegar a 52 tha (Fontes, 1973).

O cultivo do quiabeiro tradicional é realizado, predominantemente, através de semeadura direta, onde são colocadas de 4 a 5 sementes/cova (Minami et al., 1997) ou até de 5 a 8, confome as recomendações técnicas para o Estado de São Paulo (Jorge et al., 1990), consumindo assim de 4 a 8 kg de sementes/ha. Este gasto exagerado deve-se ao fato das sementes apresentarem dormência devido à impermeabilidade do tegumento (Medina, 1971), que promove uma germinação desuniforme e um tanto demorada. Este fato é acentuado quando a semente possui menos de $12 \%$ de umidade relativa, o que pode ocorrer quando esta foi submetida a secagem muito prolongada ou 
por ter sido armazenada em local com baixa umidade relativa, inferior a $60 \%$ (Minami et al., 1997).

Outro fator importante no início do cultivo é a exigência de temperaturas mais elevadas, sendo que a temperatura ótima para germinação das sementes se situa na faixa de 21 à $35^{\circ} \mathrm{C}$ (Sementes Hortec, 1995), limite que é obtido, dependendo da região, somente em algumas épocas do ano, restringindo assim, a época de plantio da cultura.

A produção de mudas pode ser uma alternativa quando é sabido que as sementes de uma determinada espécie ou variedade são menos vigorosas e necessitam de um maior cuidado na fase de germinação e emergência (Minami, 1995).

$\mathrm{Na}$ cultura do quiabeiro, quando é feita a produção de mudas, esta é realizada pelo próprio produtor como parte do sistema adotado, ou seja, semeadura em canteiros ou sementeiras, transplante das mudas para o local definitivo, colheita e comercialização dos frutos. Segundo Minami (1995) este sistema de produção pode trazer alguns inconvenientes, que sempre se traduzem em perda de eficiência, dentre os quais podemos destacar:

- o agricultor nem sempre é um bom produtor de mudas, deixando a produção de mudas à segundo plano, pois pela prática ele prefere cuidar mais da parte de campo;

- o local reservado ao viveiro de mudas, ou à sementeira, nem sempre é adequado;

- o sistema é pouco eficiente quanto a parte fitossanitária, pois é vulnerável e exposto às condições ambientais;

- as sementes ficam em condições bastante desuniformes (solo, temperatura, chuva) e consequentemente, a germinação e emergência também são irregulares, originando plântulas irregulares, com "stands" ruins. 
A utilização de recipientes para a produção de mudas é um sistema que vem sendo empregado em diferentes hortaliças nas mais importantes regiões olerícolas do Brasil e de outros países (Coelho, 1980).

Alguns fatores têm intensificado a utilização de recipientes na produção de mudas de hortaliças, pois o sistema proporciona menor interferência no sistema radicular, devido ao não rompimento das raízes por ocasião do transplante, evitando ou diminuindo a incidência de várias doenças. Isto proporciona maior proteção à muda, maior porcentagem de pegamento e maior uniformidade. Além disso, há uma maior facilidade de manuseio das mudas com torrão e possibilidade do uso intensivo da área disponivel (Cannel et al., 1966; Cheng \& Santos, 1973; Vieira, 1977; Ferreira, 1978; Silva Junior \& Visconti, 1991).

Segundo Taveira (1996), as principais funções dos recipientes para a produção de mudas são: proporcionar um meio para suportar e nutrir as plantas, proteger as raizes dos danos mecânicos e dissecação, dar uma conformação vantajosa para as raízes das mudas e maximizar a sobrevivência no campo, pois o sistema radicular não é danificado e permanece em contato íntimo com o substrato.

Vários tipos de recipientes têm sido testados e utilizados para a produção de mudas de diferentes espécies olerícolas. Dentre eles podemos destacar os copos de papel de jornal, copos de plástico, fertilpot e sacos plásticos, entre outros. Estes tipos de embalagens são descritos por Tessarioli Neto (1995) como embalagens para acondicionamento individual. De maneira geral, estes recipientes são confeccionados ou comprados pelo próprio agricultor e a produção das mudas, também neste caso, se restringe a uma área da própria propriedade, continuando assim, à cargo do agricultor.

Outro sistema que utiliza recipientes é o da produção de mudas em bandejas ou em embalagens para condicionamento coletivo. Este sistema não é recente, pois vem sendo utilizado há quase vinte anos, comercialmente, tanto na Europa como nos Estados Unidos e possibilitou o abertura de um outro tipo 
de profissional na área olerícola, o produtor de mudas especializado (Minami, 1995). As bandejas são geralmente constituídas de isopor, sendo possivel a sua reutilização. Além disso, permitem economia de espaço e de substrato a ser utilizado (Oliveira et al., 1993).

Em algumas regiões do Brasil, a produção de mudas de certas espécies olerícolas, como tomate, alface e pepino já é uma atividade comercial que, na maioria das vezes, independe do agricultor final. Mas, a viabilidade de introdução de outras espécies neste sistema ainda é muito carente e precisa ser melhor estudado.

Segundo Barros (1997), a produção comercial de mudas de hortaliças utiliza basicamente ambiente protegido, irrigação, substrato, bandeja, entre outros, os quais associados podem determinar a duração do cultivo e aumentar a economia da produção.

O tamanho do recipiente, e o tipo do substrato são os primeiros aspectos a serem investigados para que seja garantida a produção de mudas de boa qualidade. O primeiro afeta diretamente o volume disponivel para o desenvolvimento das raízes (Latimer, 1991). Sendo assim, ele deve permitir o desenvolvimento sem que haja restrições significativas do sistema radicular (Jesus, et al, 1987).

Estudos realizados por Ruff et al. (1987) mostram que houve redução no desenvolvimento e alterações na morfologia do sistema radicular de plantas de tomate quando estas foram submetidas na fase inicial a determinados tipos de recipiente. Weston \& Zandstra (1986), trabalhando com diferentes tamanhos de bandejas para a produção de mudas de tomate e a sua interferência na instalação da cultura no campo, verificaram que plantas provenientes de bandejas cujo volume de célula era maior, começavam a produzir mais cedo que aquelas provenientes de células menores. Entretanto, a produção total não foi diferente entre os dois tipos de muda. Isto foi atribuido ao menor trauma sofrido pelas raízes durante o transplante, pois as plantas originadas de células maiores apresentavam o sistema radicular mais desenvolvido. Isto 
concorda com Nicklow \& Minges (1963) e Knavel (1965) que verificaram que mudas provenientes de células com volume maior apresentavam mais folhas, maior taxa de desenvolvimento após o transplante e precocidade na produção. Em berinjela, conforme resultados obtidos por Gorski \& Wertz (1985), além da precocidade de produção, houve diferença na produtividade pois as mudas provenientes de células maiores apresentaram aumento na produção. Portanto, a interferência do tamanho do recipiente na produtividade pode variar de acordo com hortaliça em questão.

Em contrapartida, a produção de mudas em bandejas com volumes menores diminui o custo do processo produtivo, pois estas ocupam menor espaço dentro da casa-de-vegetação.

A profundidade e o formato das células também podem afetar 0 desenvolvimento da muda. Trabalhos realizados por Liptay \& Edwards (1994) verificaram que o desenvolvimento do sistema radicular aumentou à medida que se aumentava a profundidade da célula.

Da mesma forma que o recipiente, o substrato exerce uma influência marcante na arquitetura do sistema radicular (Spurr \& Barnes, 1982) e no estado nutricional das plantas, afetando profundamente a qualidade das mudas (Carneiro, 1983).

No mercado há diversos modelos de bandejas de isopor com formas e volumes de células diferentes, podendo ser redondas, piramidais, cilindricas, etc. A profundidade também pode ser variável, sendo encontradas bandejas de 47, 60 e $120 \mathrm{~mm}$ (Minami, 1995). Assim também, estão disponiveis várias formulações de substratos, produzidos especialmente para a produção de mudas olericolas.

Estudos sobre a avaliação de métodos de semeadura para a produção de mudas na cultura do quiabeiro foram realizados por Pereira et al. (1995). Neste trabalho os autores compararam a semeadura direta e a indireta em bandejas de 72, 128 e 200 células e verificaram que a velocidade de germinação foi mais rápida quando se utilizou bandejas para a semeadura. 
Sendo assim, a produção de mudas neste sistema já possibilitou alguma melhoria, pois como foi mencionado, a germinação das sementes de quiabo é problemática. Mas, as diferenças de mudas formadas entre os diversos tipos de bandejas existentes ainda é um ponto que precisa ser melhor elucidado. 


\section{MATERIAL E MÉTODOS}

O experimento foi conduzido na área experimental do Departamento de Horticultura da Escola Superior de Agricultura "Luiz de Queiroz", no município de Piracicaba, Estado de São Paulo, com latitude $22^{\circ} 43^{\prime}$ Sul, longitude $47^{\circ} 38^{\prime}$ Oeste e altitude de $540 \mathrm{~m}$. Segundo a classificação de KÖPPEN, o clima da região é Cwa: tropical úmido, com três meses mais secos (jun./jul./ago.), chuva de verão e seca de inverno, temperatura do mês mais quente $>22^{\circ} \mathrm{C}$ e média de $21,4^{\circ} \mathrm{C}$, precipitação de 1.278 milímetros, ventos predominantes $1^{\underline{a}}$ Este e $2^{\text {a }}$ Sudoeste com velocidade média de 2,2 metros por segundo, umidade relativa do ar de $71,5 \%$ e insolação média diária de 7,7 horas/dia (Tabela 1). Os dados meteorológicos (média mensal) do período experimental estão descritos na Tabela 2.

O trabalho foi realizado em duas etapas:

* Produção de mudas em ambiente protegido no sistema de bandejas de isopor;

* Transplante destas mudas em campo e avaliação da produção comercial de frutos.

\subsection{Produção de mudas}

\subsubsection{Caracterização do local}

A produção de mudas ocorreu em ambiente protegido, sendo que a estrutura utilizada é do tipo arco, com cobertura de plástico transparente de 
150 micra e laterais revestidas de tela (sombrite de 50\%). Apresenta como medidas internas comprimento de $21,7 \mathrm{~m}$; largura de $4,7 \mathrm{~m}$ e $3,3 \mathrm{~m}$ de altura máxima.

Tabela 1. Dados meteorológicos no período 1917-1996 (Estação Agrometeorológica da Esalq/USP, Departamento de Física e Meteorologia. Piracicaba - SP), 1997.

\begin{tabular}{lcccc} 
Mês & $\begin{array}{c}\text { Temperatura Média } \\
\left({ }^{\circ} \mathbf{C}\right)\end{array}$ & $\begin{array}{c}\text { Precipitação } \\
(\mathbf{m m})\end{array}$ & $\begin{array}{c}\text { UR } \\
(\%)\end{array}$ & $\begin{array}{c}\text { Insolação } \\
\text { (h/mês) }\end{array}$ \\
\hline Jan & 24,3 & 225,8 & 76,0 & 6,4 \\
Fev & 24,6 & 186,4 & 75,0 & 6,6 \\
Mar & 24,0 & 143,1 & 76,0 & 6,8 \\
Abr & 21,8 & 65,4 & 74,0 & 7,5 \\
Mai & 19,1 & 53,5 & 75,0 & 7,3 \\
Jun & 17,6 & 43,4 & 74,0 & 7,1 \\
Jul & 17,3 & 27,7 & 69,0 & 7,9 \\
Ago & 19,1 & 29,7 & 64,0 & 8,2 \\
Set & 20,7 & 61.7 & 64,0 & 6,9 \\
Out & 22,2 & 109,2 & 69,0 & 6,9 \\
Nov & 23,1 & 130,1 & 69,0 & 7,4 \\
Dez & 23,8 & 202,0 & 74,0 & 6,6 \\
& & & & \\
\hline & $\mathbf{2 1 , 4}$ & $2=1.278$ & $\mathbf{x}=71,5$ & $\mathbf{x}=7,7$ \\
\hline
\end{tabular}


Tabela 2. Dados meteorológicos durante o período experimental, no município de Piracicaba - SP (Estação Agrometeorológica da Esalq/USP Departamento de Física e Meteorologia, Piracicaba - SP), 1997

\begin{tabular}{lcccc} 
Mês & $\begin{array}{c}\text { Temperatura } \\
\left({ }^{\circ} \mathbf{C}\right)\end{array}$ & $\begin{array}{c}\text { UR } \\
(\%)\end{array}$ & $\begin{array}{c}\text { Precipitação } \\
(\mathbf{m m})\end{array}$ & $\begin{array}{c}\text { Radiação Global } \\
(\mathbf{M J}-2 \mathbf{d}-\mathbf{)})\end{array}$ \\
\hline Fev & 23,9 & 81,5 & 87,1 & 21,8 \\
Mar & 22,7 & 77,1 & 73,1 & 19,5 \\
Abr & 20,9 & 77,0 & 19,9 & 17,4 \\
Mai & 18,5 & 79,4 & 55,2 & 13,9 \\
Jun & 16,6 & 84,8 & 108,6 & 11,4 \\
\hline
\end{tabular}

\subsubsection{Tratamentos adotados}

Para a produção de mudas utilizou-se o sistema de bandejas de isopor, sendo que foram avaliados três tipos de bandejas, que diferem entre si pelo volume e altura das células, associadas a quatro diferentes substratos.

As bandejas são de poliestireno expandido (isopor), possuem $68 \mathrm{~cm}$ de comprimento por $34 \mathrm{~cm}$ de largura e alturas variáveis dependendo do tipo. As características das bandejas estão descritas na Tabela 3.

Os sustratos utilizados eram compostos basicamente de uma formulação comercial na qual foram feitas diferentes associações com outros materiais ou com suplementação de adubação. A caracterização dos substratos encontra-se na Tabela 4. 
Tabela 3. Caracterização das bandejas utilizadas

\begin{tabular}{lcccc} 
Bandeja & $\begin{array}{c}\text { Número de } \\
\text { células }\end{array}$ & $\begin{array}{c}\text { Volume das células } \\
\left(\mathbf{c m}^{\mathbf{3}}\right)\end{array}$ & $\begin{array}{c}\text { Altura } \\
(\mathbf{m m})\end{array}$ & Disposição \\
\hline T1 & 128 & 72 & 120 & $16 \times 8$ \\
T2 & 128 & 36 & 60 & $16 \times 8$ \\
T3 & 200 & 16 & 47 & $20 \times 10$ \\
\hline
\end{tabular}

Tabela 4. Caracterização dos substratos utilizados

Substratos

Descrição
A
Gll (Produto comercial)
B
Gll associado a suplementação mineral
C
GII sem adubação básica feita pelo fabricante, associada a suplementação mineral
D
Gll misturado com casca de arroz carbonizada na proporção 1:1, associada a suplementação mineral

Os substratos $\mathrm{A}, \mathrm{B}$ e $\mathrm{C}$ foram compostos a partir do produto comercial GII, o qual é fabricado pela Empresa Gioplanta - Comércio e Representação Agricola Ltda. e constituido pela mistura de casca de pinus compostada, casca de arroz carbonizada, vermiculita grossa número 12 , calcário dolomítico e a seguinte adubação básica: fertilizante 4-14-8, FTE-BR9 e Superfosfato 
Simples. Para o substrato $\mathrm{C}$ foi encomendado ao fabricante o produto Gll sem a adubação básica.

Para a suplementação mineral utilizou-se a aplicação do adubo mineral Petters, cuja composição de elementos é dada por $20 \% \mathrm{~N} ; 10 \% \mathrm{P} ; 20 \% \mathrm{~K}$; $0,15 \% \mathrm{Mg} ; 0,02 \% \mathrm{~B} ; 0,01 \% \mathrm{Cu} ; 0,1 \% \mathrm{Fe} ; 0,056 \% \mathrm{Mn} ; 0,01 \% \mathrm{Mo} ; 0,0162 \% \mathrm{Zn}$.

\subsubsection{Instalação e condução}

Foram utilizadas 48 bandejas de poliestireno expandido, lavadas e desinfetadas com uma solução de Hipoclorito de Sódio comercial à 10\%.

No dia 09/02/97 estas bandejas foram preenchidas com o sustrato, de acordo com o tratamento e posteriormente foram semeadas 2 sementes/célula da cultivar de quiabo Santa Cruz - 47. Após a semeadura foi realizada uma irrigação, as bandejas foram então levadas à casa de vegetação e apoiadas em suportes de ferro a $0,80 \mathrm{~m}$ do piso.

O início da germinação ocorreu aos 3 dias a partir da semeadura, sendo que no $6^{\circ}$ dia $90 \%$ das plantas já tinham emergido. 0 desbaste ocorreu 8 dias após a semeadura deixando-se então somente 1 planta/célula.

Como parte dos tratamentos utilizados foram realizadas 5 suplementações minerais nos dias 18/02; 22/02; 25/02; $01 / 03$ e 5/03. Estas suplementações consistiram na aplicação de 0,300 l/bandeja do adubo solúvel Petters, na concentração $1 \mathrm{~g} / \mathrm{l}$ nos tratamentos que apresentavam como substrato aqueles denominados $\mathrm{B}, \mathrm{C}$ e $\mathrm{D}$, conforme a tabela 4 .

$\mathrm{Na}$ casa de vegetação estas bandejas permaneceram até o dia 13/03, sendo que durante este período a irrigação por microaspersão foi realizada através de um sistema automatizado. Normalmente eram realizadas 5 irrigações durante o dia, sendo que a programação do horário e intervalo de molhamento variavam conforme as condições de temperatura e umidade do ambiente. 


\subsubsection{Delineamento experimental}

O delineamento experimental adotado foi o aleaotorizado em esquema fatorial $3 \times 4$, sendo três níveis de bandejas $(T 1, T 2, T 3)$ e quatro de substratos (A, B, C, D). Cada parcela experimental foi composta por uma bandeja contendo uma planta/célula.

Segundo este modelo, cada bloco foi formado pela combinação dos tipos de bandejas e de substratos, que repetidos em quatro blocos, totalizaram 48 bandejas.

Foram realizadas cinco avaliações, em intervalos de cinco dias, sendo que em cada uma delas foram amostradas 8 plantas, obtendo-se o valor médio de cada avaliação.

O esquema adotado para a análise da variância consta na tabela 5 . As médias foram comparadas pelo teste de Tukey ao nível de $5 \%$ de probabilidade, de acordo com Gomes (1990).

$\mathrm{Na}$ análise dos dados utilizou-se o programa computacional SAS (Statistical Analysis System Institute, 1985).

Tabela 5: Esquema de análise de variância para as causas de variação

Causas de variação

Graus de liberdade

Tipos de Bandeja (B) 2

Tipos de Substrato (S) 3

$B * S \quad 6$

Blocos 3

Resíduo 33 


\subsubsection{Parâmetros avaliados}

Para análise de crescimento das mudas foram realizadas cinco avaliações aos $12,17,22,27,32$ dias à partir da semeadura, visando acompanhar o desenvolvimento das plantas nas bandejas e substratos utilizados. Nestas avaliações foram analisados os seguintes parâmetros:

- Área foliar (AF)

- Altura da parte aérea (APA)

- Diâmetro da parte mediana do caule (DC)

- Peso da matéria seca da parte aérea (PMSA)

- Peso da matéria seca do sistema radicular (PMSR)

Para a obtenção dos valores da área foliar foram retiradas as folhas, com o auxilio de uma tesoura, de oito plantas/bandeja. Estas folhas foram acondicionadas em sacos de plástico fechados, etiquetados e mantidos sob refrigeração. Posteriormente estes sacos foram levados para o laboratório onde as folhas foram submetidas ao aparelho Área - Meter, modelo 3100 , obtendo-se assim a leitura direta dos valores da área foliar total das oito plantas, em $\mathrm{cm}^{2}$.

Para a obtenção da altura da parte aérea (APA) e diâmetro da parte mediana do caule (DC), as plantas, agora já sem folhas, foram retiradas das bandejas, levadas ao laboratório e lavadas em água corrente para a retirada do substrato aderente. O diâmetro da parte mediana foi obtido através do uso de um paquímetro e a altura com o auxílio de um régua graduada em milímetros. Posteriormente, as plantas foram seccionadas na altura do colo, colocadas separadamente, parte aérea e sistema radicular, em sacos de papel etiquetados e submetidas à estufa de secagem e esterilização FANEM, modelo $320-S E$ de circulação mecânica, para secagem à $65^{\circ} \mathrm{C}$. Quando o peso 
constante foi atingido efetuou-se a pesagem na balança eletrônica digital ACATEC, modelo BEC 1000, obtendo-se os pesos da matéria seca da parte aérea e do sistema radicular. Para a obtenção do peso da parte aérea, antes da secagem, foram adicionadas as folhas anteriormente retiradas

\subsection{Produção de frutos}

\subsubsection{Caracterização do local}

A cultura foi estabelecida através do transplante direto das mudas no campo experimental do Departamento de Horticultura. Segundo Vidal-Torrado \& Sparovek (1993), o solo desta área é descrito como Terra Roxa Estruturada Eutrófica: A moderado textura argilosa sobre muito argilosa; correspondente ao Kandiudalfic Eutrudox. Procedeu-se a análise química antes do plantio para fins de fertilidade, de acordo com Raij et al. (1987) (Tabelas 6 e 7).

Tabela 6. Resultado da Análise de solo da área experimental. (Setor de Nutrição Mineral de Plantas, Departamento de Química da Escola Superior de Agricultura "Luiz de Queiroz", Piracicaba $\mathrm{SP})$.

$\mathrm{meq} / 100 \mathrm{~cm} 3$

$\begin{array}{llllllllll}\text { P res. } & \text { M.O. } & \mathrm{pH} & \mathrm{K} & \mathrm{Ca} & \mathrm{Mg} & \mathrm{H}+\mathrm{Al} & \mathrm{S} & \mathrm{T} & \mathrm{V} \%\end{array}$ $\% \mathrm{CaCl}$

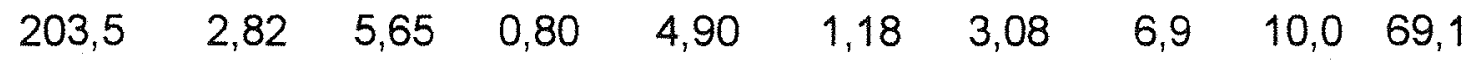


Tabela 7. Resultado da Análise de solo (micronutrientes, em ppm) da área experimental. (Setor de Nutrição Mineral de Plantas, Departamento de Química da Escola Superior de Agricultura "Luiz de Queiroz", Piracicaba - SP).

\begin{tabular}{cccccc}
\hline B & Cu & Fe & Mn & Mo & Zn \\
\hline 0,40 & 15,6 & 51,8 & 106,7 & - & 15,3 \\
\hline
\end{tabular}

\subsubsection{Instalação da cultura}

Para o preparo do solo foram realizadas uma aração e duas gradagens. Posteriormente foi feito o sulcamento, distando os sulcos de $1 \mathrm{~m}$ e com profundidade de $5 \mathrm{~cm}$. Não foi efetuada adubação de plantio devido ao alto teor de nutrientes revelados na análise de solo do local. A adubação de cobertura foi dividida em duas parcelas, aplicadas aos 30 e 60 dias após o transplante, empregando $10 \mathrm{~g} / \mathrm{planta}$ de nitrocálcio.

O transplante das mudas ocorreu após 31 dias da semeadura, sendo realizado no período da manhã e também no final da tarde do dia 12/03. 0 espaçamento adotado foi de 0,5 m entre plantas e 1,0 m entre linhas,

Após o transplante foi realizada uma irrigação por aspersão e durante as primeiras semanas esta foi quase que diária. Posteriormente, após o pegamento das mudas e estabelecimento da cultura no campo, estas eram realizadas em intervalos maiores ( 2 a 3 vezes por semana).

Os tratos culturais constaram do controle de pragas e doenças conforme o necessário. Para o controle de plantas daninhas foram realizadas capinas 
manuais, com intervalo de aproximadamente 15 dias, durante todo o ciclo da cultura.

\subsubsection{Delineamento experimental}

O delineamento experimental adotado foi o mesmo utilizado na primeira etapa (produção de mudas), sendo que foram transplantadas 30 mudas de cada um dos doze tratamentos. Cada parcela experimental constou de 5 fileiras de $3,0 \mathrm{~m}$ de comprimento, totalizando uma área de $15 \mathrm{~m}^{2}$ com 30 plantas/parcela. Como área útil foram consideradas as 12 plantas centrais utilizando-se as linhas laterais como bordadura.

\subsubsection{Parâmetros estimados}

Os critérios de avaliação foram número e peso total dos frutos por parcela.

A colheita iniciou-se 49 dias após o transplante das mudas no campo, quando os frutos se apresentavam no ponto comercial, ou seja, com 8 a $10 \mathrm{~cm}$ de comprimento.

Foram efetuadas 7 colheitas, sendo que eram colhidos os frutos, das doze plantas centrais, de cada parcela separadamente. Posteriormente estes frutos eram levados para o laboratório, contados e pesados em balança de precisão da marca Marte.

Ao final do período de colheita obteve-se o peso e o número total de frutos por parcela, chegando-se assim a determinação da produção. 


\section{RESULTADOS E DISCUSSÃO}

\subsection{Resultados da avaliação das mudas}

\subsection{1 Área foliar (AF)}

Pelos resultados obtidos na Tabela 8 observa-se que, na primeira avaliação, o desenvolvimento das plantas de quiabeiro dependeu do substrato e da bandeja utilizados.

As plantas produzidas na bandeja T1 apresentaram, na maioria das vezes, uma maior média de área foliar nos quatro diferentes substratos, exceto quando tratou-se do substrato $D$, onde os valores entre a bandeja $T 1$ e T2 não diferiram estatisticamente.

$\mathrm{Na}$ segunda época de avaliação (Tabela 9), a dependência do tipo de bandeja foi maior que na primeira, sendo que, para os dois primeiros tipos de substratos ( $A$ e B), os três tipos de bandejas não mostraram diferenças no desenvolvimento da área foliar. $\mathrm{Na}$ bandeja $\mathrm{T} 3$ não houve diferença entre nenhum dos quatro tipos de substratos. Quanto ao tipo de bandeja, observouse que para os quatro diferentes substratos a bandeja $\mathrm{T} 1$ se mostrou superior em desenvolvimento da área foliar, quando comparada com as bandejas T2 e T3. Os menores valores de área foliar foram obtidos para as bandejas T3, quando preenchidas com os substratos $\mathrm{A}$ e B. 
Tabela 8. Médias obtidas, em $\mathrm{cm}^{2}$, para área foliar (AF) das mudas de quiabeiro produzidas nos diferentes tipos de bandejas e substratos, referentes a primeira avaliação.

\section{Bandejas}

\begin{tabular}{|c|c|c|c|c|}
\hline Substratos $^{1}$ & T1 & T2 & T3 & Média \\
\hline$A$ & 5,675 a $A$ & $2,425 \quad b \quad B$ & $2,738 \mathrm{ab} \quad \mathrm{B}$ & 3,607 \\
\hline B & 5,392 a $A$ & $3,780 \mathrm{a}$ & 2,888 a $\quad B$ & 4,020 \\
\hline C & $4,444 a b A$ & 2,303 b $B$ & $2,451 \mathrm{ab} B$ & 3,066 \\
\hline $\mathrm{D}$ & 3,548 b A & $2,779 a b A B$ & 1,871 b $B$ & 2,733 \\
\hline Média & 4,760 & 2,822 & 2,487 & \\
\hline
\end{tabular}

\footnotetext{
Médias seguidas por letras diferentes, maiúscula na linha e minúscula na coluna, diferem entre si pelo teste de Tukey à $5 \%$.

Dados transformados $x^{0,3}$

$\mathrm{CV}=5,95$
}

Tabela 9. Médias obtidas, em $\mathrm{cm}^{2}$, para área foliar (AF) das mudas de quiabeiro produzidas nos diferentes tipos de bandejas e substratos, referentes a segunda avaliação.

\section{Bandejas}

\begin{tabular}{|c|c|c|c|c|}
\hline Substratos ${ }^{1}$ & T1 & T2 & T3 & Média \\
\hline $\bar{A}$ & $27,330 \mathrm{aA}$ & $8,817 a b \quad B$ & $5,563 a \quad C$ & 13,904 \\
\hline B & $30,675 a \mathrm{~A}$ & $13,553 a \quad B$ & $7,038 a$ & 17,089 \\
\hline C & $13,260 \mathrm{bA}$ & $8,079 b \quad B$ & $6,455 a \quad B$ & 9,264 \\
\hline D & $10,617 \mathrm{bA}$ & $4,554 \subset B$ & $3,859 a \quad B$ & 6,343 \\
\hline Média & 20,470 & 8,751 & 5,729 & \\
\hline
\end{tabular}

\footnotetext{
Tédias seguidas por letras diferentes, maiúscula na linha e minúscula na coluna, diferem entre si pelo teste de Tukey à $5 \%$.

Dados transformados $x^{0,3}$

$\mathrm{CV}=7,82 \%$
} 
Conforme os dados apresentados nas Tabela 10, 11 e 12 observou-se que, a partir da terceira avaliação (Tabela 10), nos quatro diferentes substratos, a bandeja T1 apresentou as maiores médias de área foliar. Esta é a bandeja que apresenta o maior volume disponível ao sistema radicular, quando comparada às outras duas. Sendo assim, a partir dos 22 dias, a restrição de volume celular para o desenvolvimento do sistema radicular pode acarretar diminuição do desenvolvimento da parte aérea, resultando em menor área foliar.

Nestas tabelas também observa-se que; de uma maneira geral, o substrato B sempre apresentou numericamente as maiores médias de área foliar nos três tipos de bandejas testados, embora observando-se que, algumas vezes, e para determinadas épocas e bandejas, seus valores não diferissem estatisticamente dos substratos $A$ e $C$. O substrato $D$, nos três tipos de bandejas estudados, sempre apresentou as menores médias de área foliar.

Tabela 10. Médias obtidas, em $\mathrm{cm}^{2}$, para área foliar (AF) das mudas de quiabeiro produzidas nos diferentes tipos de bandejas e substratos, referentes a terceira avaliação.

Bandejas

\begin{tabular}{|c|c|c|c|c|}
\hline Substratos $^{1}$ & T1 & T2 & T3 & Média \\
\hline $\bar{A}$ & $47,331 a \mathrm{~A}$ & $18,328 \mathrm{~b} B$ & $9,592 \mathrm{~b} \quad \mathrm{C}$ & 25,101 \\
\hline B & $60,357 a A$ & $27,530 a \quad B$ & $14,872 a \quad C$ & 34,253 \\
\hline C & 31,149 b A & $18,570 \mathrm{~b} \quad \mathrm{~B}$ & $12,720 a b \quad C$ & 20,813 \\
\hline D & $19,140 \mathrm{cA}$ & 10,027 c B & 5,214 c C & 11,461 \\
\hline Média & 39,494 & 18,627 & 10,600 & \\
\hline
\end{tabular}

\footnotetext{
'Médias seguidas por letras diferentes, maiúscula na linha e minúscula na coluna, diferem entre si pelo teste de Tukey à $5 \%$.

Dados transformados $x^{0,3}$

CV $=5,18 \%$
} 
Tabela 11. Médias obtidas, em $\mathrm{cm}^{2}$, para área foliar (AF) das mudas de quiabeiro produzidas nos diferentes tipos de bandejas e substratos, referentes a quarta avaliação.

\section{Bandejas}

Substratos $^{1}$

T1 T2

T3

Média

\begin{tabular}{|c|c|c|c|c|}
\hline$A$ & $61,368 \mathrm{a} \quad \mathrm{A}$ & 23,191 b B & $12,408 \mathrm{~b} \quad \mathrm{C}$ & 32,323 \\
\hline B & $67,008 a A$ & $41,505 a \quad B$ & $20,617 a$ & 43,043 \\
\hline C & 39,940 b A & $25,305 \mathrm{~b} \quad \mathrm{~B}$ & $16,350 \mathrm{ab}$ & 27,198 \\
\hline D & $25,303 \mathrm{cA}$ & 13,593 с B & 7,892 & 15,596 \\
\hline Média & 48,405 & 25,899 & 14,317 & \\
\hline
\end{tabular}

\footnotetext{
Tédias seguidas por letras diferentes, maiúscula na linha e minúscula na coluna, diferem entre si pelo teste de Tukey à $5 \%$.

Dados transformados $x^{0,3}$

CV $=4,53 \%$
}

Tabela 12. Médias obtidas, em $\mathrm{cm}^{2}$, para área foliar (AF) das mudas de quiabeiro produzidas nos diferentes tipos de bandejas e substratos, referentes a quinta avaliação.

\section{Bandejas}

Substratos $^{1}$

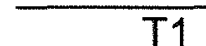

T2

T3

Média

\begin{tabular}{|c|c|c|c|c|}
\hline $\bar{A}$ & $63,874 a b A$ & 26,325 b B & 14,432 b C & 34,877 \\
\hline B & $73,471 \mathrm{a} \quad$ A & $36,745 a \quad B$ & $23,306 a \quad C$ & 44,507 \\
\hline C & 53,092 b A & $31,152 \mathrm{ab} B$ & $18,847 a b C$ & 34,363 \\
\hline D & 29,451 CA & 16,678 & 9,354 & 18,495 \\
\hline Média & 54,972 & 27,725 & 16,484 & \\
\hline
\end{tabular}

\footnotetext{
'Médias seguidas por letras diferentes, maiúscula na linha e minúscula na coluna, diferem entre si pelo teste de Tukey à $5 \%$.

Dados transformados $\mathrm{x}^{0,3}$

$\mathrm{CV}=3,01 \%$
} 


\subsubsection{Altura da parte aérea (APA)}

Os dados obtidos na primeira avaliação (Tabela 13), mostram que, a maior altura das plantas de quiabeiro, em determinada bandeja, depende do substrato em questão e assim, reciprocamente. Isto também foi verificado no parâmetro área foliar, mas nem sempre os resultados encontrados em cada época de avaliação eram semelhantes nestes dois parâmetros avaliados, principalmente quando se tratava das primeiras épocas. Este fato decorre das pequenas dimensões analisadas nas primeiras avaliações, o que pode ocasionar erros de leitura.

Tabela 13. Médias obtidas, em $\mathrm{cm}$, para altura da parte aérea (APA) das mudas de quiabeiro produzidas nos diferentes tipos de bandejas e substratos, referentes a primeira avaliação.

Bandejas

Substratos $^{1}$

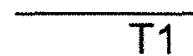

T1

T2

T3

Média

\begin{tabular}{|c|c|c|c|c|}
\hline$A$ & $6,927 a \mathrm{~A}$ & $5,297 a$ B & 5,859 b $\quad B$ & 6,039 \\
\hline B & $5,669 \mathrm{bA}$ & $5,640 a \mathrm{~A}$ & $6,003 a \quad A$ & 5,771 \\
\hline C & $5,950 \mathrm{bA}$ & $4,881 a$ B & $5,034 \mathrm{bc} \quad \mathrm{B}$ & 5,288 \\
\hline D & $5,541 \mathrm{bA}$ & $5,484 a A$ & $4,956 \mathrm{cA}$ & 5,327 \\
\hline Média & 6,030 & 5,326 & 5,463 & \\
\hline
\end{tabular}

Tédias seguidas por letras diferentes, maiúscula na linha e minúscula na coluna, diferem entre si pelo teste de Tukey à $5 \%$.

Dados transformados $\mathrm{x}^{0,6}$

$\mathrm{CV}=4,74 \%$

À partir da segunda avaliação (Tabela 14) observa-se que a bandeja T1 sempre propiciou as maiores alturas de plantas, quando comparadas aos dois 
outros tipos de bandeja, e que isto se mantém ao longo das demais avaliações (Tabelas 15, 16, 17).

Tabela 14. Médias obtidas, em $\mathrm{cm}$, para altura da parte aérea (APA) das mudas de quiabeiro produzidas nos diferentes tipos de bandejas e substratos, referentes a segunda avaliação.

\section{Bandejas}

\begin{tabular}{|c|c|c|c|c|}
\hline Substratos ${ }^{1}$ & T1 & T2 & T3 & Média \\
\hline $\bar{A}$ & $14,828 a \mathrm{~A}$ & 9,331 b B & $10,019 a \quad B$ & 11,393 \\
\hline B & $14,653 a A$ & $11,828 a \quad B$ & $10,862 a B$ & 12,448 \\
\hline C & $12,069 \mathrm{~b} \mathrm{~A}$ & 9,344 b B & $9,509 a \quad B$ & 10,307 \\
\hline D & $9,794 \mathrm{cA}$ & $8,575 \mathrm{bAB}$ & 7,378 b B & 8,582 \\
\hline Média & 12,836 & 9,769 & 9,442 & \\
\hline
\end{tabular}

\footnotetext{
'Médias seguidas por letras diferentes, maiúscula na linha e minúscula na coluna, diferem entre si pelo teste de Tukey à $5 \%$.

Dados transformados $x^{0.6}$

$\mathrm{CV}=6,07 \%$
}

De maneira geral, a partir da terceira avaliação, assim como ocorreu com a área foliar, os maiores valores da altura da parte aérea foram obtidos com os tratamentos que utilizaram o substrato $B$, embora em algumas épocas de avaliação ele não diferisse estatisticamente dos substratos $A$ e $C$. $O$ substrato $D$, também conforme o parâmetro área foliar, foi o que apresentou as menores médias para as medidas de altura. 
Tabela 15. Médias obtidas, em $\mathrm{cm}$, para altura da parte aérea (APA) das mudas de quiabeiro produzidas nos diferentes tipos de bandejas e substratos, referentes a terceira avaliação.

\begin{tabular}{|c|c|c|c|c|}
\hline \multirow[b]{2}{*}{ Substratos ${ }^{1}$} & \multicolumn{3}{|c|}{ Bandejas } & \multirow[b]{2}{*}{ Média } \\
\hline & T1 & T2 & T3 & \\
\hline$A$ & 21,919 & 13,369 & 12,672 & $15,986 \mathrm{~b}$ \\
\hline B & 22,162 & 17,752 & 15,584 & $18,490 a$ \\
\hline C & 18,306 & 13,053 & 12,697 & $14,685 b$ \\
\hline$D$ & 13,540 & 10,665 & 9,222 & 11,142 \\
\hline Média & $18,982 A$ & $13,703 \mathrm{~B}$ & $12,544 \mathrm{~B}$ & \\
\hline
\end{tabular}

Tabela 16. Médias obtidas, em $\mathrm{cm}$, para altura da parte aérea (APA) das mudas de quiabeiro produzidas nos diferentes tipos de bandejas e substratos, referentes a quarta avaliação.

\section{Bandejas}

Substratos $^{1}$

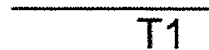

T1

T2

T3

Média

\begin{tabular}{|c|c|c|c|c|}
\hline$A$ & $28,456 a \mathrm{~A}$ & $16,540 \mathrm{~b} \mathrm{~B}$ & $15,944 a \quad B$ & 20,313 \\
\hline B & 26,047 a A & $21,522 a \quad B$ & $16,369 a \quad C$ & 21,440 \\
\hline $\mathrm{C}^{\prime}$ & $21,759 \mathrm{bA}$ & $16,369 \mathrm{~b} \mathrm{~B}$ & $14,875 a \quad B$ & 17,668 \\
\hline D & $17,334 \mathrm{bA}$ & 12,462 & $10,184 \mathrm{bB}$ & 13,327 \\
\hline Média & 23,399 & 16,723 & 14,439 & \\
\hline
\end{tabular}

\footnotetext{
Médias seguidas por letras diferentes, maiúscula na linha e minúscula na coluna, diferem entre si pelo teste de Tukey à $5 \%$.

Dados transformados $x^{0,6}$

$\mathrm{CV}=6,38 \%$
} 
Tabela 17. Médias obtidas, em $\mathrm{cm}$, para altura da parte aérea (APA) das mudas de quiabeiro produzidas nos diferentes tipos de bandejas e substratos, referentes a quinta avaliação.

Bandejas

\begin{tabular}{lrrrr}
\cline { 2 - 4 } Substratos & T1 & T2 & T3 & Média \\
\hline A & 25,740 & 15,781 & 15,456 & $18,992 \mathrm{ab}$ \\
B & 27,278 & 22,053 & 19,875 & $23,069 \mathrm{a}$ \\
C & 22,928 & 16,666 & 15,606 & $18,400 \mathrm{ab}$ \\
D & 17,015 & 13,722 & 10,490 & $13,759 \mathrm{~b}$
\end{tabular}

\begin{tabular}{llll}
\hline Média & $23,240 \mathrm{~A}$ & $17,068 \mathrm{~B}$ & $15,357 \mathrm{~B}$
\end{tabular}

\footnotetext{
Tédias seguidas por letras diferentes, maiúscula na linha e minúscula na coluna, diferem entre si pelo teste de Tukey à $5 \%$.

Dados transformados $x^{0,8}$

$\mathrm{CV}=7,69 \%$
}

\subsubsection{Diâmetro da parte mediana do caule (DC)}

No caso deste parâmetro, diferentemente do que ocorreu com os dois anteriores, não houve dependência entre os tipos de bandejas e os diferentes substratos na maioria das avaliações, excetuando-se somente a segunda.

$\mathrm{Na}$ primeira avaliação (Tabela 18), já existiam diferenças entre as plantas provenientes da bandeja de maior volume (T1) e as demais, sendo que estas apresentaram menor diâmetro.

À partir da segunda avaliação (Tabela 19), esta diferença foi acentuando-se cada vez mais, chegando na terceira, quarta e quinta avaliações (Tabelas $20,21,22$ ) à diferenças bastante pronunciadas, onde as mudas proveniente da bandeja T3 apresentavam sempre maiores diâmetros. 
Tabela 18. Médias obtidas, em mm, para diâmetro da parte mediana do caule (DC), das mudas de quiabeiro produzidas nos diferentes tipos de bandejas e substratos, referentes a primeira avaliação.

\section{Bandejas}

\begin{tabular}{|c|c|c|c|c|}
\hline Substratos $^{1}$ & T1 & T2 & T3 & Média \\
\hline $\bar{A}$ & 2,403 & 2,230 & 2,022 & $2,218 a b$ \\
\hline B & 2,398 & 2,259 & 2,095 & $2,251 a$ \\
\hline C & 2,222 & 1,981 & 1,932 & $2,045 \mathrm{~b}$ \\
\hline D & 2,162 & 2,033 & 1,933 & $2,042 \mathrm{~b}$ \\
\hline Média & $2,296 \mathrm{~A}$ & $2,125 B$ & $1,995 \mathrm{~B}$ & \\
\hline
\end{tabular}

\footnotetext{
TMédias seguidas por letras diferentes, maiúscula na linha e minúscula na coluna, diferem entre si pelo teste de Tukey à $5 \%$.

Dados transformados $x^{-0,4}$

$\mathrm{CV}=3,45 \%$
}

Tabela 19. Médias obtidas, em $\mathrm{mm}$, para diâmetro da parte mediana do caule (DC), das mudas de quiabeiro produzidas nos diferentes tipos de bandejas e substratos, referentes a segunda avaliação.

\section{Bandejas}

Substratos ${ }^{1}$

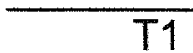

T1

T2

T3

Média

\begin{tabular}{|c|c|c|c|c|}
\hline $\bar{A}$ & $2,809 a b \mathrm{~A}$ & $2,497 \quad b \quad B$ & $2,184 a \quad C$ & 2,497 \\
\hline B & $3,032 a \quad A$ & $2,756 a$ & $2,326 a \quad B$ & 2,705 \\
\hline C & $2,593 \mathrm{bA}$ & 2,387 bc $A B$ & $2,211 a$ B & 2,397 \\
\hline D & $2,614 \mathrm{~b} \mathrm{~A}$ & 2,172 & 1,860 b C & 2,215 \\
\hline Média & 2,762 & 2,453 & 2,145 & \\
\hline
\end{tabular}

\footnotetext{
Médias seguidas por letras diferentes, maiúscula na linha e minúscula na coluna, diferem entre si pelo teste de Tukey à $5 \%$.

Dados transformados $x^{-0,4}$

CV $=2,07 \%$
} 
Tabela 20. Médias obtidas, em mm, para diâmetro da parte mediana do caule (DC), das mudas de quiabeiro produzidas nos diferentes tipos de bandejas e substratos, referentes a terceira avaliação.

\section{Bandejas}

Substratos $^{1}$

T1

T2

T3

Média

\begin{tabular}{lllll}
\hline A & 3,386 & 2,517 & 2,021 & $2,641 \mathrm{~b}$ \\
B & 3,693 & 2,987 & 2,311 & $3,004 \mathrm{a}$ \\
C & 2,957 & 2,553 & 2,198 & $2,569 \mathrm{~b}$ \\
D & 2,750 & 2,187 & 1,750 & $2,229 \mathrm{c}$
\end{tabular}

\section{Média}

3,196A

2,561

$2,057 \mathrm{C}$

\footnotetext{
Médias seguidas por letras diferentes, maiúscula na linha e minúscula na coluna, diferem entre si pelo teste de Tukey à $5 \%$.

Dados transformados $x^{-0,4}$

$\mathrm{CV}=3,21 \%$
}

Tabela 21. Médias obtidas, em mm, para diâmetro da parte mediana do caule (DC), das mudas de quiabeiro produzidas nos diferentes tipos de bandejas e substratos, referentes a quarta avaliação.

\section{Bandejas}

Substratos $^{1}$

T1 T2

T3

Média

\begin{tabular}{lllll}
\hline A & 3,559 & 2,846 & 2,233 & $2,879 \mathrm{~b}$ \\
$\mathrm{~B}$ & 3,658 & 3,281 & 2,408 & $3,115 \mathrm{a}$ \\
$\mathrm{C}$ & 3,247 & 2,792 & 2,390 & $2,810 \mathrm{~b}$ \\
$\mathrm{D}$ & 2,950 & 2,579 & 2,054 & $2,582 \mathrm{C}$ \\
\hline Média & $3,353 \mathrm{~A}$ & $2,874 \mathrm{~B}$ & $2,271 \mathrm{C}$ &
\end{tabular}

\footnotetext{
Médias seguidas por letras diferentes, maiúscula na linha e minúscula na coluna, diferem entre si pelo teste de Tukey à $5 \%$.

Dados transformados $\mathrm{x}^{-0,4}$

CV $=2,77 \%$
} 
Tabela 22. Médias obtidas, em mm, para diâmetro da parte mediana do caule (DC), das mudas de quiabeiro produzidas nos diferentes tipos de bandejas e substratos, referentes a quinta avaliação.

\begin{tabular}{|c|c|c|c|c|}
\hline \multirow[b]{2}{*}{ Substratos ${ }^{1}$} & \multicolumn{3}{|c|}{ Bandejas } & \multirow[b]{2}{*}{ Média } \\
\hline & T1 & T2 & T3 & \\
\hline $\bar{A}$ & 3,540 & 2,748 & 2,197 & $2,828 b$ \\
\hline B & 3,823 & 3,076 & 2,490 & $3,130 a$ \\
\hline$C$ & 3,306 & 2,836 & 2,423 & $2,855 b$ \\
\hline$D$ & 2,889 & 2,576 & 2,036 & $2,500 \quad c$ \\
\hline Média & $3,390 \mathrm{~A}$ & $2,809 \mathrm{~B}$ & $2,286 \quad C$ & \\
\hline
\end{tabular}

Quanto aos diferentes substratos, à partir da terceira avaliação, observase que o substrato $D$ foi o que propiciou mudas de maior diâmetro. Já os substratos $A$ e $B$, não apresentavam diferenças entre si e o substrato $B$ foi $o$ que proporcionou mudas de menor diâmetro.

Comparando-se estes resultados com aqueles referentes às medidas de altura, observa-se um comportamento inverso. Com isso, temos que as mudas que apresentaram maiores altura (aquelas provenientes do substrato B) apresentaram o menor diâmetro e aquelas com menores alturas (provenientes do substrato D), os maiores diâmetros. 


\subsubsection{Peso da matéria seca da parte aérea (PMSA)}

Comparando-se os valores obtidos nas cinco avaliações (Tabelas 23, $24,25,26$ e 27), observa-se que as maiores médias de peso da matéria seca da parte aérea para um determinado tipo de bandeja, de maneira geral, dependem do substrato em questão. Isto coincide com o que foi obtido nas avaliações para os outros parâmetros da parte aérea (área foliar, altura da planta).

Tabela 23. Médias obtidas, em g, para peso da matéria seca da parte aérea (PMSA), das mudas de quiabeiro produzidas nos diferentes tipos de bandejas e substratos, referentes a primeira avaliação.

\begin{tabular}{|c|c|c|c|c|}
\hline \multirow[b]{2}{*}{ Substratos ${ }^{1}$} & \multicolumn{3}{|c|}{ Bandejas } & \multirow[b]{2}{*}{ Média } \\
\hline & $\overline{T 1}$ & T2 & T3 & \\
\hline $\bar{A}$ & $0,104 a A$ & $0,074 a b B$ & $0,084 a \quad B$ & 0,087 \\
\hline B & $0,084 \mathrm{~b} \mathrm{~A}$ & $0,075 \mathrm{abA}$ & $0,079 a b A$ & 0,080 \\
\hline C & $0,070 \mathrm{bcA}$ & $0,064 \mathrm{bA}$ & $0,068 \mathrm{bA}$ & 0,067 \\
\hline$D$ & $0,063 \subset B$ & $0,083 a A$ & $0,078 a b A$ & 0,075 \\
\hline Média & 0,080 & 0,074 & 0,077 & \\
\hline
\end{tabular}


Tabela 24. Médias obtidas, em g, para peso da matéria seca da parte aérea (PMSA), das mudas de quiabeiro produzidas nos diferentes tipos de bandejas e substratos, referentes a segunda avaliação.

\begin{tabular}{lcccc}
\hline & \multicolumn{3}{c}{ Bandejas } & \\
\cline { 2 - 4 } Substratos $^{1}$ & T1 & T2 & T3 & Média \\
\hline A & $0,224 a \mathrm{~A}$ & $0,148 \mathrm{~b}$ B & $0,139 \mathrm{a} \quad \mathrm{C}$ & 0,170 \\
$\mathrm{~B}$ & $0,231 \mathrm{a} \mathrm{A}$ & $0,180 \mathrm{a}$ B & $0,140 \mathrm{a} \quad \mathrm{C}$ & 0,184 \\
$\mathrm{C}$ & $0,147 \mathrm{bA}$ & $0,128 \mathrm{bAB}$ & $0,120 \mathrm{a} \mathrm{B}$ & 0,132 \\
D & $0,138 \mathrm{bA}$ & $0,130 \mathrm{bAB}$ & $0,115 \mathrm{a} \mathrm{B}$ & 0,127 \\
\hline Média & 0,185 & 0,147 & 0,128 &
\end{tabular}

\footnotetext{
Médias seguidas por letras diferentes, maiúscula na linha e minúscula na coluna, diferem entre si pelo teste de Tukey à $5 \%$.

Dados transformados $x^{0,01}$

$\mathrm{CV}=0,09 \%$
}

À partir da terceira avaliação (Tabela 25) observa-se que houve maior discriminação nos valores de peso da matéria seca da parte aérea entre os três tipos de bandejas estudados, separando-os em três grupos. Este comportamento também foi verificado na avaliação da área foliar. Sendo assim, as mudas originárias da bandeja T1, apresentaram maiores valores de área foliar e também apresentam maior valor de peso seco da parte aérea. Da mesma forma, a bandeja T2 situa-se na posição intermediária para os dois parâmetros e, finalizando, as plantas da bandeja T3 foram as que apresentaram menores médias de área foliar e de peso da matéria seca da parte aérea. 
Tabela 25. Médias obtidas, em g, para peso da matéria seca da parte aérea (PMSA), das mudas de quiabeiro produzidas nos diferentes tipos de bandejas e substratos, referentes a terceira avaliação.

\begin{tabular}{|c|c|c|c|c|}
\hline \multirow[b]{2}{*}{ Substratos ${ }^{1}$} & \multicolumn{3}{|c|}{ Bandejas } & \multirow[b]{2}{*}{ Média } \\
\hline & $\overline{\mathrm{T1}}$ & T2 & T3 & \\
\hline $\bar{A}$ & 0,358 & 0,230 & 0,167 & $0,252 b$ \\
\hline B & 0,369 & 0,287 & 0,193 & $0,283 a$ \\
\hline C & 0,289 & 0,198 & 0,167 & $0,218 c$ \\
\hline D & 0,222 & 0,174 & 0,140 & $0,179 \quad d$ \\
\hline Média & $0,309 \mathrm{~A}$ & $0,222 \mathrm{~B}$ & $0,167 \mathrm{C}$ & \\
\hline
\end{tabular}

\footnotetext{
'Médias seguidas por letras diferentes, maiúscula na linha e minúscula na coluna, diferem entre si pelo teste de Tukey à $5 \%$.

Dados transformados $x^{0,01}$

$\mathrm{CV}=0,10 \%$
}

Tabela 26. Médias obtidas, em g, para peso da matéria seca da parte aérea (PMSA), das mudas de quiabeiro produzidas nos diferentes tipos de bandejas e substratos, referentes a quarta avaliação.

\section{Bandejas}

Substratos

$\mathrm{T} 1$

T2

T3

Média

\begin{tabular}{lllll}
\hline A & $0,560 a \mathrm{~A}$ & $0,303 \mathrm{~b} B$ & $0,212 \mathrm{~b} \mathrm{C}$ & 0,358 \\
$\mathrm{~B}$ & $0,575 \mathrm{a} A$ & $0,410 \mathrm{a}$ & $0,264 \mathrm{a} \quad \mathrm{C}$ & 0,416 \\
$\mathrm{C}$ & $0,384 \mathrm{bA}$ & $0,284 \mathrm{~b} \mathrm{~B}$ & $0,215 \mathrm{~b} \mathrm{C}$ & 0,295 \\
D & $0,281 \mathrm{bA}$ & $0,209 \mathrm{cB}$ & $0,164 \mathrm{cC}$ & 0,218 \\
\hline Média & 0,450 & 0,301 & 0,214 &
\end{tabular}

\footnotetext{
Médias seguidas por letras diferentes, maiúscula na linha e minúscula na coluna, diferem entre si pelo teste de Tukey à $5 \%$.

Dados transformados $x^{0,01}$

$\mathrm{CV}=0,10 \%$
} 
Tabela 27. Médias obtidas, em g, para peso da matéria seca da parte aérea (PMSA), das mudas de quiabeiro produzidas nos diferentes tipos de bandejas e substratos, referentes a quinta avaliação.

\begin{tabular}{|c|c|c|c|c|}
\hline \multirow[b]{2}{*}{ Substratos $^{1}$} & \multicolumn{3}{|c|}{ Bandejas } & \multirow[b]{2}{*}{ Média } \\
\hline & $\overline{T 1}$ & T2 & T3 & \\
\hline 1 & 0,712 & 0,351 & 0,235 & $0,433 b$ \\
\hline 2 & 0,752 & 0,521 & 0,317 & $0,530 a$ \\
\hline 3 & 0,530 & 0,353 & 0,252 & $0,378 \mathrm{~b}$ \\
\hline 4 & 0,345 & 0,240 & 0,162 & $0,249 \mathrm{c}$ \\
\hline
\end{tabular}

\footnotetext{
Tédias seguidas por letras diferentes, maiúscula na linha e minúscula na coluna, diferem entre si pelo teste de Tukey à $5 \%$.

Dados transformados $x^{0,01}$

$C V=0,13 \%$
}

Quanto aos diferentes substratos, de maneira geral, aquele denominado $B$, foi o que proporcionou mudas com maiores médias de peso da matéria seca da parte aérea, embora em algumas épocas de avaliações ele não diferisse do substrato A. Na quinta avaliação (Tabela 27), o mesmo comportamento que vinha ocorrendo com os outros parâmetros analisados para o substrato $D$ foi verificado, ou seja, este substrato proporcionou mudas com os menores pesos de parte aérea.

\subsubsection{Peso da matéria seca do sistema radicular (PMSR)}

Para o peso da matéria seca do sistema radicular a dependência dos dois fatores (bandeja e substrato) também ocorreu, embora em menor escala (somente em duas épocas de avaliação). 
$\mathrm{Na}$ primeira avaliação (Tabela 28), observa-se que a bandeja T1, contrariamente ao esperado, foi a que apresentou menores valores de peso da matéria seca do sistema radicular. Isto pode ter ocorrido devido a dificuldade de se retirar a maior quantidade de substrato aderido às raízes em plantas de apenas 12 dias.

Tabela 28. Médias obtidas, em g, para peso da matéria seca do sistema radicular, das mudas de quiabeiro produzidas nos diferentes tipos de bandejas e substratos, referentes a primeira avaliação.

\begin{tabular}{lllll}
\hline & \multicolumn{3}{c}{ Bandejas } & \\
\cline { 2 - 4 } Substratos $^{1}$ & T1 & \multicolumn{2}{c}{ T2 } & T3 \\
\hline A & 0,012 & 0,016 & 0,018 & $0,015 a$ \\
B & 0,009 & 0,017 & 0,017 & $0,014 a$ \\
C & 0,016 & 0,017 & 0,016 & $0,016 a$ \\
D & 0,016 & 0,022 & 0,016 & $0,018 a$ \\
\hline Média & $0,013 \mathrm{~B}$ & $0,018 \mathrm{~A}$ & $0,016 \mathrm{~A}$ &
\end{tabular}

\footnotetext{
'Médias seguidas por letras diferentes, maiúscula na linha e minúscula na coluna, diferem entre si pelo teste de Tukey à $5 \%$.

Dados transformados $x^{0,2}$

$\mathrm{CV}=5,23 \%$
}

$\mathrm{Na}$ segunda avaliação (Tabela 29) este comportamento começa a inverter e, assim como aconteceu com os outros parâmetros, à partir da terceira avaliação (Tabelas 30, 31 e 32) as mudas provenientes da bandeja de maior volume (T1) eram as que apresentavam maiores médias de peso da matéria seca do sistema radicular. 
Tabela 29. Médias obtidas, em g, para peso da matéria seca do sistema radicular, das mudas de quiabeiro produzidas nos diferentes tipos de bandejas e substratos, referentes a segunda avaliação.

\section{Bandejas}

Substratos ${ }^{1}$

T1

T2

T3

Média

\begin{tabular}{lllll}
\hline A & $0,034 a \mathrm{AB}$ & $0,044 a b A$ & $0,030 \mathrm{a} \mathrm{B}$ & 0,036 \\
B & $0,031 \mathrm{a}$ B & $0,051 \mathrm{a} \mathrm{A}$ & $0,030 \mathrm{a} \mathrm{B}$ & 0,037 \\
C & $0,038 \mathrm{a}$ A & $0,034 \mathrm{bA}$ & $0,035 \mathrm{aA}$ & 0,036 \\
D & $0,039 a \mathrm{~A}$ & $0,044 \mathrm{abA}$ & $0,024 \mathrm{a} \mathrm{B}$ & 0,036
\end{tabular}

\section{Média}

$$
0,035
$$

0,043

0,030

\footnotetext{
'Médias seguidas por letras diferentes, maiúscula na linha e minúscula na coluna, diferem entre si pelo teste de Tukey à $5 \%$.

Dados transformados $x^{0.2}$

$\mathrm{CV}=4,00 \%$
}

Tabela 30. Médias obtidas, em g, para peso da matéria seca do sistema radicular, das mudas de quiabeiro produzidas nos diferentes tipos de bandejas e substratos, referentes a terceira avaliação.

\section{Bandejas}

Substratos $^{1}$

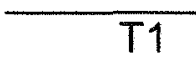

T1

T2

T3

Média

\begin{tabular}{lllll}
\hline A & 0,099 & 0,066 & 0,039 & $0,068 \mathrm{a}$ \\
B & 0,097 & 0,070 & 0,042 & $0,070 \mathrm{a}$ \\
C & 0,068 & 0,063 & 0,043 & $0,058 \mathrm{ab}$ \\
D & 0,062 & 0,054 & 0,032 & $0,049 \mathrm{~b}$
\end{tabular}

Média

$0,081 \mathrm{~A}$

$0,063 \mathrm{~B}$

$0,039 \mathrm{C}$

\footnotetext{
TMédias seguidas por letras diferentes, maiúscula na linha e minúscula na coluna, diferem entre sí pelo teste de Tukey à $5 \%$.

Dados transformados $x^{0,2}$

$\mathrm{CV}=3,26 \%$
} 
Quanto aos diferentes substratos utilizados, observou-se que, de maneira geral, o substrato $B$ foi o que apresentou as maiores médias de peso da matéria seca do sistema radicular, embora na maioria das avaliações ele não diferisse estatisticamente dos substratos $A$ e $C$. $O$ substrato $D$, como também ocorreu nos outros parâmetros analisados, foi o que apresentou as menores médias mas, neste parâmetro, as diferenças não foram tão marcante, pois muitas vezes seus valores, apesar de menores, não diferiram estatisticamente dos substratos $\mathrm{A}$ e $\mathrm{C}$.

Tabela 31. Médias obtidas, em g, para peso da matéria seca do sistema radicular, das mudas de quiabeiro produzidas nos diferentes tipos de bandejas e substratos, referentes a quarta avaliação.

\section{Bandejas}

Substratos ${ }^{1}$

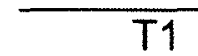

T1

$\mathrm{T} 2$

T3

Média

\begin{tabular}{lllll}
\hline A & 0,150 & 0,096 & 0,054 & $0,100 \mathrm{ab}$ \\
B & 0,142 & 0,115 & 0,060 & $0,105 \mathrm{a}$ \\
$\mathrm{C}$ & 0,113 & 0,088 & 0,057 & $0,086 \mathrm{~b}$ \\
$\mathrm{D}$ & 0,092 & 0,065 & 0,040 & $0,065 \mathrm{c}$ \\
\hline Média & $0,124 \mathrm{~A}$ & $0,091 \mathrm{~B}$ & $0,053 \mathrm{C}$ &
\end{tabular}

\footnotetext{
${ }^{\top}$ Médias seguidas por letras diferentes, maiúscula na linha e minúscula na coluna, diferem entre si pelo teste de Tukey à $5 \%$.

Dados transformados $x^{0,2}$

$\mathrm{CV}=3,01 \%$
} 
Tabela 32. Médias obtidas, em g, para peso da matéria seca do sistema radicular, das mudas de quiabeiro produzidas nos diferentes tipos de bandejas e substratos, referentes a quinta avaliação.

\begin{tabular}{|c|c|c|c|c|}
\hline \multirow[b]{2}{*}{ Substratos $^{1}$} & \multicolumn{3}{|c|}{ Bandejas } & \multirow[b]{2}{*}{ Média } \\
\hline & T1 & T2 & T3 & \\
\hline $\bar{A}$ & $0,221 a \mathrm{~A}$ & $0,109 \mathrm{~b} \quad \mathrm{~B}$ & $0,069 a b C$ & 0,133 \\
\hline B & $0,216 a \mathrm{~A}$ & $0,144 a \quad B$ & $0,081 a \quad C$ & 0,147 \\
\hline C & $0,158 \mathrm{bA}$ & $0,113 a b$ B & $0,077 a \quad C$ & 0,116 \\
\hline D & $0,116 \mathrm{bA}$ & $0,090 \mathrm{~b} \mathrm{~B}$ & 0,055 b C & 0,087 \\
\hline Média & 0,178 & 0,114 & 0,071 & \\
\hline
\end{tabular}

\footnotetext{
'Médias seguidas por letras diferentes, maiúscula na linha e minúscula na coluna, diferem entre si pelo teste de Tukey à $5 \%$.

Dados transformados $\mathrm{x}^{0,2}$

$\mathrm{CV}=2,8 \%$
}

\subsection{Discussão dos resultados da produção de mudas}

Pelos resultados obtidos e considerando-se as três últimas avaliações, observa-se nos gráficos 1, 2, 3 e 4 que as maiores médias sempre ocorreram nas mudas provenientes de bandejas com maior volume celular (T1). Vale ressaltar que, embora sendo minoria, para alguns dos parâmetros avaliados este resultado era dependente do substrato utilizado.

Nos parâmetros área foliar $(A F)$, peso da matéria seca da parte aérea (PMSA) e peso da matéria seca do sistema radicular (PMSR) as bandejas T2 e T3 também apresentaram diferenças entre si, sendo que a T3, foi a que proporcionou a formação de mudas com as menores médias. Estes resultados concordam com o obtido por Barros (1997), que avaliando a produção de mudas de tomate e pepino em diferentes recipientes verificou que bandejas 
com maior volume de células proporcionavam mudas maiores em AF, PMSA e PMSR.

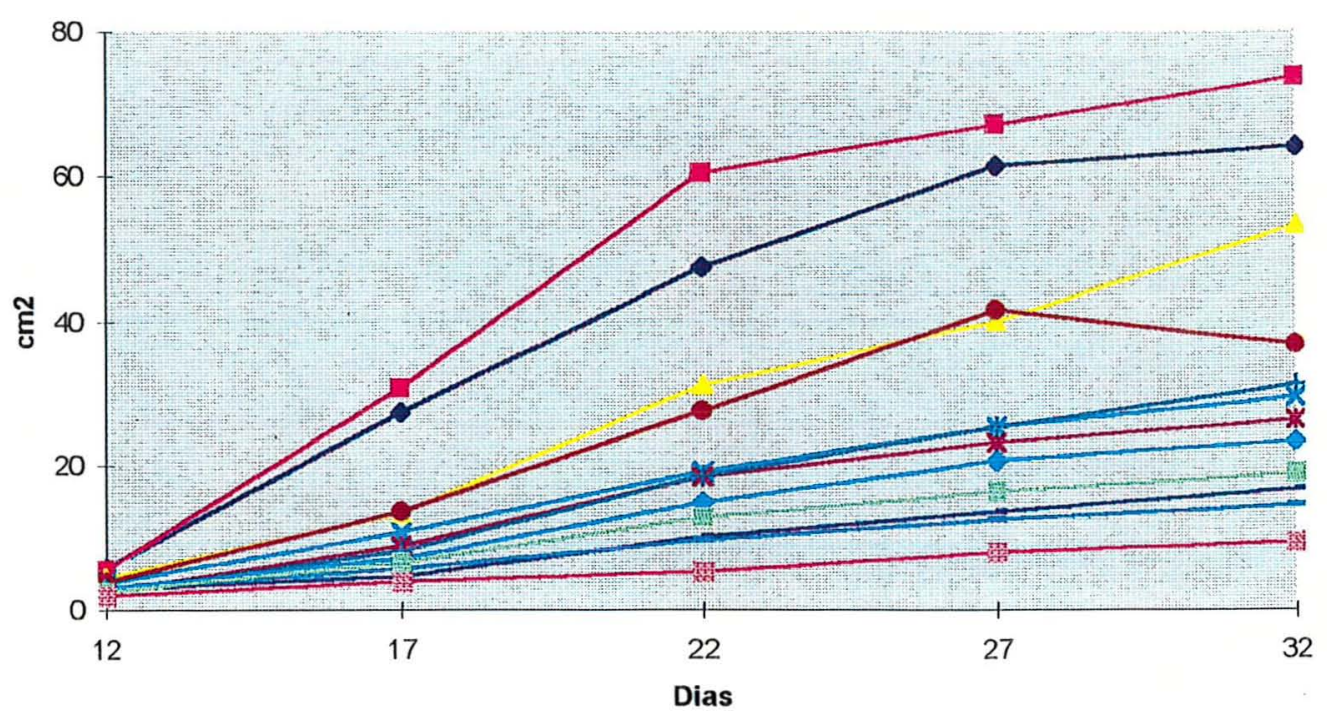

$\rightarrow \quad$ Tratamento 1: Bandeja T1 e Substrato A

$\rightarrow$ - Tratamento 2:Bandeja T1 e Substrato B Tratamento 3:Bandeja T1 e Substrato C

$* \quad$ Tratamento 4:Bandeja T1 e Substrato D

* Tratamento 5:Bandeja T2 e Substrato A

$\rightarrow \quad$ Tratamento 6:Bandeja T2 e Substrato B

+ Tratamento 7: Bandeja T2 e Substrato C

- Tratamento 8: Bandeja T2 e Substrato D

— Tratamento 9: Bandeja T3 e Substrato A

— Tratamento 10: Bandeja T3 e Substrato B

- Tratamento 11: Bandeja T3 e Substrato C

一琶- Tratamento 12: Bandeja T3 e Substrato D

Figura 1: Médias de área foliar (AF), de acordo com os tratamentos, nas cinco épocas de avaliação. 


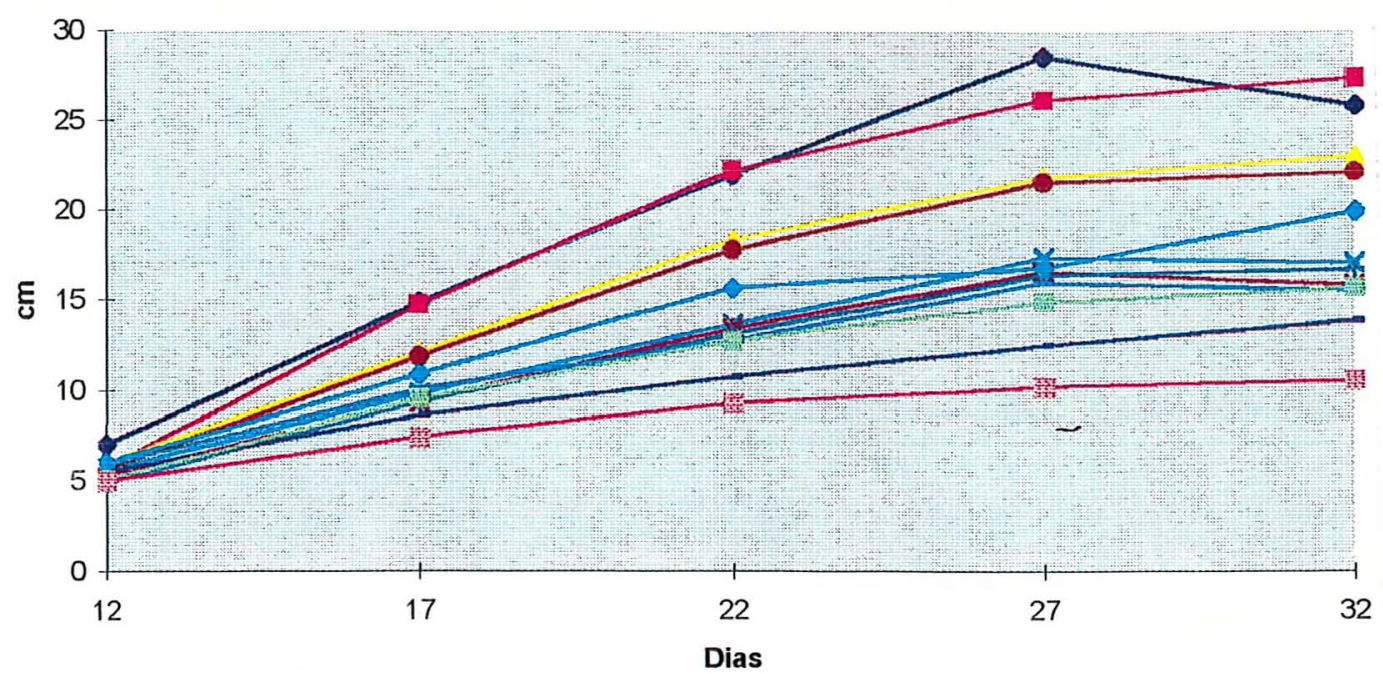

Figura 2: Médias de altura da parte aérea (APA), de acordo com os tratamentos, nas cinco épocas de avaliação.

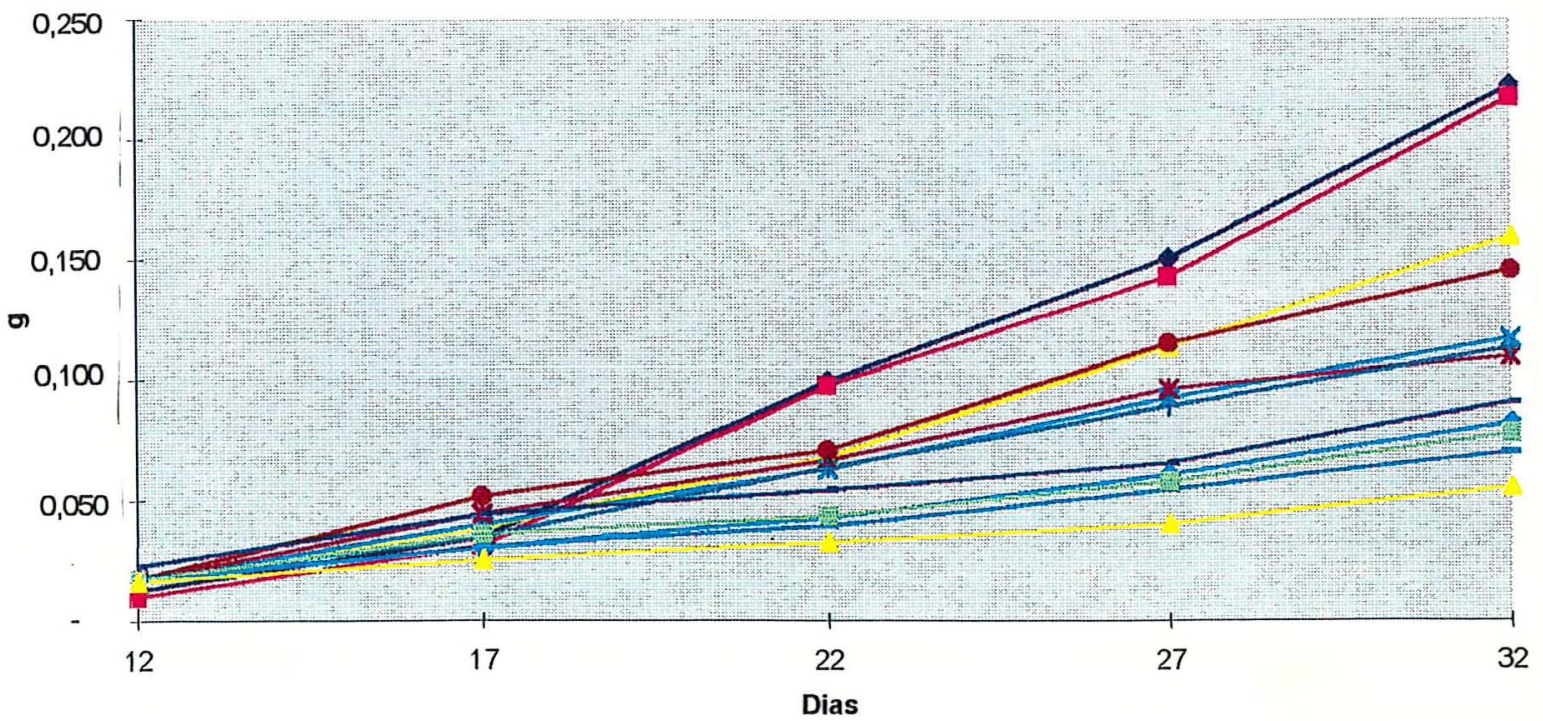

Figura 3: Médias de peso da matéria seca da parte aérea (PMSA), de acordo com os tratamentos, nas cinco épocas de avaliação. 


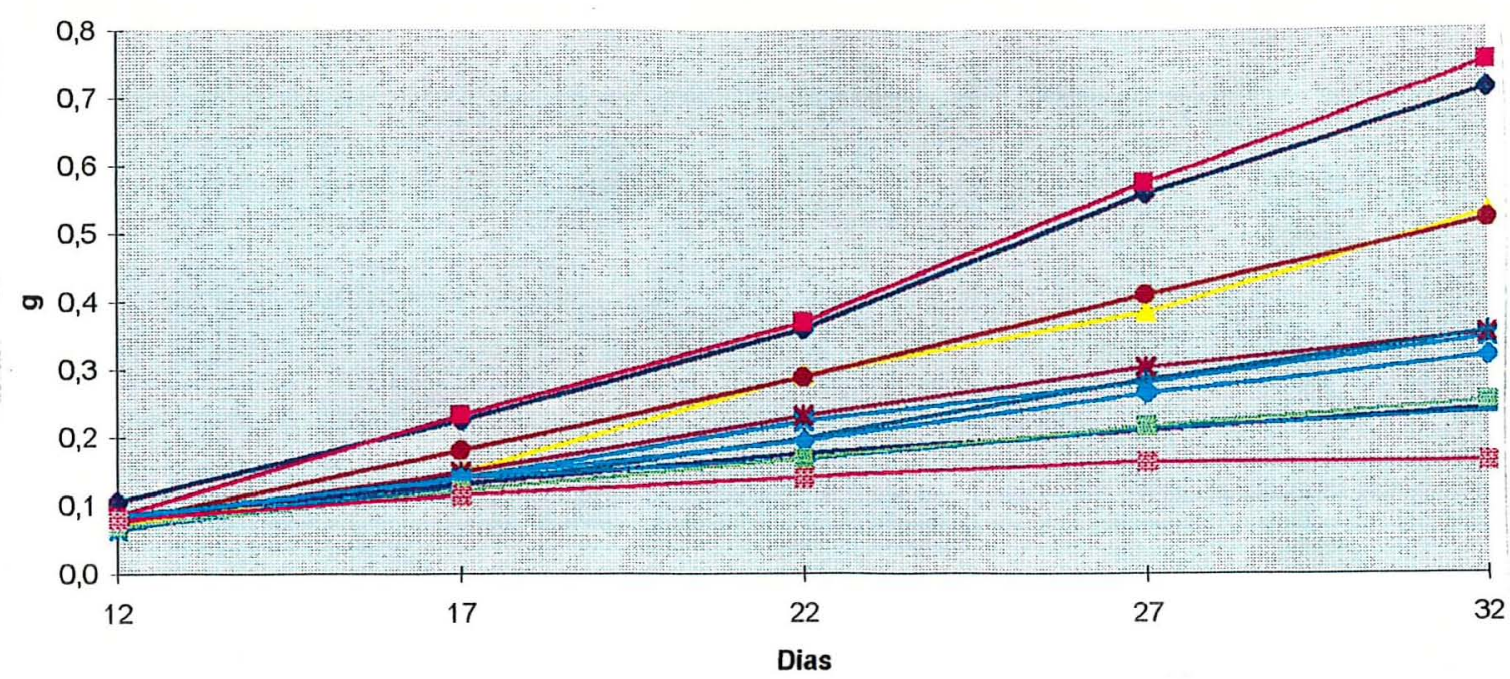

Figura 4: Médias de peso da matéria seca do sistema radicular (PMSR), de acordo com os tratamentos, nas cinco épocas de avaliação.

Oliveira et al. (1993), avaliando a produção de mudas de maracujazeiro, observaram que o melhor desenvolvimento destas ocorreu quando foram utilizadas bandejas com células de maior volume, independente do substrato utilizado. Estes autores acreditam que isto se deve provavelmente ao maior volume que está envolvendo o sistema radicular, propiciando condições mais satisfatórias para o desenvolvimento das mudas.

Quanto aos diferentes tipos de substratos, verificou-se que houve dependência do tipo de bandeja utilizada. De maneira geral, o substrato $B$ foi o que proporcionou mudas com maiores médias para os parâmetros estudados, embora, dependendo do tipo de bandeja, ele não diferisse dos substratos $\mathrm{A}$ e C.

Este comportamento ocorreu contrariamente para as medidas de diâmetro do caule, onde o substrato $\mathrm{B}$ foi o que originou plantas de maior diâmetro. 
$O$ fato do substrato $B$ apresentar os melhores resultados para aqueles parâmetros em relação aos substratos $\mathrm{A} \in \mathrm{C}$, demonstra uma resposta positiva das plantas de quiabeiro à adubação.

Quanto ao substrato D, de maneira geral pode-se dizer que ele sempre proporcionou mudas com menores médias para os parâmetros avaliados, excetuando-se somente os valores de diâmetro do caule.

A utilização de casca de arroz carbonizada para a mistura de substratos tem sido recomendada para a produção de mudas, pois este componente apresenta boa capacidade de drenagem, baixa capacidade de retenção de umidade, $\mathrm{pH}$ ligeiramente alcalino e também por ser rico em minerais, principalmente cálcio e potássio (Gonçalvez, 1995). Possivelmente a adição deste componente no substrato $D$ não favoreceu o desenvolvimento das mudas devido a proporção utilizada (1:1), pois vale ressaltar, que a única diferença entre os substratos B e D é a presença da casca de arroz. Esta proporção pode ter alterado as características físicas da mistura, prejudicando o desenvolvimento do sistema radicular e, consequentemente, da parte aérea. Isto também foi verificado no momento do transplante, pois as mudas provenientes do substrato $D$, independente da bandeja utilizada, não formavam torrão, dificultando assim o seu transplante.

\subsection{Resultados obtidos na avaliação da produção de frutos}

\subsubsection{Produção em número de frutos}

Como se observa na Tabela 33, as plantas originadas das mudas provenientes da bandeja de maior volume (T1), produziram maior quantidade de frutos que aquelas provenientes da bandeja de menor volume (T3). Isto 
ocorreu independentemente do substrato utilizado. A bandeja de volume intermediário (T2) não diferiu das demais.

Tabela 33. Número de frutos produzidos de plantas de quiabeiro, referentes às mudas obtidas nos diferentes tipos de bandejas e substratos.

\begin{tabular}{|c|c|c|c|c|}
\hline \multirow[b]{2}{*}{ Substratos } & \multicolumn{3}{|c|}{ Bandejas } & \multirow[b]{2}{*}{ Média } \\
\hline & T1 & T2 & T3 & \\
\hline 1 & 55,66 & 50,05 & 42,63 & $48,45 a$ \\
\hline 2 & 58,16 & 43,86 & 41,50 & $47,84 a$ \\
\hline 3 & 50,95 & 54,66 & 44,89 & $50,17 a$ \\
\hline 4 & 43,00 & 36,14 & 34,99 & $38,04 b$ \\
\hline Média & $51,19 A$ & $46,18 \mathrm{AB}$ & $41,00 \mathrm{~B}$ & \\
\hline
\end{tabular}

Quanto aos diferentes substratos utilizados, observa-se que as mudas provenientes do substrato $D$, quando transplantadas para o campo, foram as que produziram menor quantidade de frutos. Os demais substratos ( $A, B$ e $C)$ não diferiram entre sí.

\subsubsection{Produção em peso de frutos}

O mesmo comportamento que ocorreu com a produção em número de frutos foi verificado para a produção em peso. Sendo assim, as plantas formadas à partir das mudas provenientes da bandeja com células de maior 
volume $(\mathrm{T} 1)$, produziram maior quantidade de frutos que as provenientes do menor volume (T3), independentemente do substrato em questão (Tabela 34). A bandeja $T 2$ não diferiu das demais.

Tabela 34. Produção de frutos, em gramas, das plantas de quiabeiro referentes às mudas obtidas nos diferentes tipos de bandejas e substratos.

\begin{tabular}{|c|c|c|c|c|}
\hline \multirow[b]{2}{*}{ Substratos } & \multicolumn{3}{|c|}{ Bandejas } & \multirow[b]{2}{*}{ Média } \\
\hline & T1 & T2 & T3 & \\
\hline 1 & 819,79 & 921,42 & 727,22 & $822,80 a$ \\
\hline 2 & 927,03 & 686,29 & 661,94 & $758,42 a$ \\
\hline 3 & 831,42 & 884,94 & 700,23 & $805,53 a$ \\
\hline 4 & 683,69 & 598,60 & 565,58 & $615,96 b$ \\
\hline Média & $815,48 \mathrm{~A}$ & $772,81 \mathrm{AB}$ & $663,74 \mathrm{~B}$ & \\
\hline
\end{tabular}

Da mesma forma, plantas originárias de mudas formadas no substrato $D$ apresentaram menor produção em peso de frutos, independente da bandeja utilizada. Os demais substratos não diferiram entre sí.

\subsection{Discussão dos resultados obtidos no campo}

Pelos resultados obtidos, observamos que a produção de frutos de quiabeiro em plantas originadas de mudas provenientes de bandejas com 
células de maior volume é maior que aquelas provenientes de bandejas com células de menor volume. Estes resultados concordam com o obtido por Gorski \& Wertz (1985) em berinjela, onde a produção também foi afetada pelo volume da célula da bandeja. Na cultura do tomate, Weston \& Zandstra (1986) não observaram este comportamento, pois não encontraram diferenças entre produtividade de frutos de plantas provenientes de mudas formadas em diferentes tamanhos de bandejas. Sendo assim, a interferência do tamanho do recipiente na produtividade pode variar de acordo com a hortaliça em estudo.

\subsection{Considerações gerais}

Algumas considerações sobre as mudas podem ser relacionadas a seguir.

Como já foi mencionado, ao se comparar os três tamanhos de bandejas estudados, constatou-se que as mudas produzidas na bandeja de maior volume celular (T1) atingiram maior tamanho em tempo menor. É possível que estas mudas pudessem ser transplantadas mais cedo, pois percebeu-se que, após o transplante, houve um certo índice de tombamento. Este fato pode ser devido ao tamanho da muda no momento do transplante.

Quanto aos substratos, observou-se que além do substrato $D$ ter proporcionado mudas de menor tamanho, no momento do transplante houve dificuldade na retirada destas mudas das bandejas, pois não houve formação de torrão.

Finalmente, como informação complementar, observou-se que o sistema de produção de mudas em bandeja, de uma forma geral, possibilita maior uniformidade de germinação, diminuindo assim os problemas de dormência das sementes de quiabeiro 


\section{CONCLUSÕES}

- As mudas de quiabeiro produzidas em bandejas com células de maior volume apresentaram os melhores resultados com relação ao seu desenvolvimento para todos os parâmetros estudados.

- A adição de casca de arroz carbonizada no substrato comercial, na proporçãoi 1:1, proporcionou menor desenvolvimento das mudas.

- A utilização de suplementação mineral ao substrato comercial favoreceu o desenvolvimento das mudas de quiabeiro.

- A produção de frutos de quiabeiro em plantas originadas de mudas provenientes de bandejas com células de maior volume foi maior que naquelas provenientes de bandejas com células de menor volume, independentemente do substrato utilizado.

- As plantas provenientes das mudas que foram formadas utilizando casca de arroz carbonizada, na proporção $1: 1$, como componente do substrato produziram menor quantidade de frutos, independentemente do tipo de bandeja utilizado.

- A modificação da adubação do substrato comercial para a produção das mudas não afetou a produção de frutos. 


\section{REFERÊNCIAS BIBLIOGRÁFICAS}

BARROS, S.B.M. Avaliação de diferentes recipientes na produção de mudas de tomate (Lycopersicon esculentum Mill.) e pepino (Cucumis sativus L.). Piracicaba, 1997. 70p. Dissertação (Mestrado) - Escola Superior de Agricultura "Luiz de Queiroz", Universidade de São Paulo.

BERNARDI, J.B. Instruções para a cultura do quiabeiro. Campinas: Instituto Agronômico da Secretaria da Agricultura e Abastecimento do Estado de São Paulo, 1957. (Boletim, 96).

CAMARGO FILHO, W.P.; MAZZEI, A.R. Hortaliças prioritárias no planejamento da produção orientada: Estacionalidade da produção e dos preços. Informações Econômicas, v.24, n.12, p.9-54, 1994.

CANNEL, G.H.; HOLLAND, A.H.; ALJIBURY, F.K. Effects of fiber containers on vegetable plant growth in field and greenhouses. California Agriculture, v. 20, n. 9, p. $7-9,1966$.

CARNEIRO, J.G. de A. Variações na metodologia de produções de mudas florestais afetam os parâmetros morfo-fisiológicos que indicam a sua qualidade. Série Técnica FUPEP, v.12, p.1-40, 1983.

CHARRIER, A. Genetic resources of Abelmoschus (OKRA). Rome: IBPGR, 1984. 61p. 
CHENG, S.S.; SANTOS, S.A.S. Efeito do número de mudas por vaso de polietileno na produção e desenvolvimento do quiabeiro (Hibiscus esculentus L.). Revista de Olericultura, v.12, p.125, 1973.

COELHO, R.G. Métodos de produção e idade de transplante de mudas de alface (Lactuca sativa L.). Viçosa, 1980. 117p. Dissertação (M.S) Universidade Federal de Viçosa.

COELHO, R.G.; LEAL, N.R.; LIBERAL, M.T. Determinação do teor de fibras em quiabo (Hibiscus esculentus L.) em função da época de colheita e comprimento dos frutos. Revista de Olericultura, v.14, p.15-16, 1974.

COSTA, M.C.B.; OLIVEIRA, G.D.; HAAG, H.P. Nutrição mineral de hortaliças Efeito da omissão dos macronutrientes e do boro, no desenvolvimento e na composição química de hortaliças. In: HAAG, H.P.; MINAMI, K. Nutrição mineral em hortaliças. Campinas: Fundação Cargil, 1981. cap. 6, p.257276.

FERREIRA, C.M. Efeito de métodos na produção de mudas na produção comercial de repolho (Brassica oleracea var capitata). Viçosa, 1978. 46p. Dissertação (M.S.) - Universidade Federal de Viçosa.

FONTES, M.R. Controlled-environment horticulture in Arabian Desert at Abu Ohabi. HortScience, v.8, n.1, p.107-115, 1973.

GOMES, F.P. Curso de estatística experimental. 13.ed. São Paulo: Nobel, 1990. 467p.

GONÇALVEZ, A.L. Substratos para a produção de plantas ornamentais. In: MINAMI, K. Produção de mudas de alta qualidade em horticultura. São Paulo: T. A. Queiroz, 1995. 128p. 
GORSKI, S.F.; WERTZ, M.K. Eggplant and tomato: a study on the effects of transplante root volume on yield. Ohio State University, 1985. (Circ., 288).

GURGEL, J.T A.; MITIDIERI, J. Estudos sobre o quiabeiro (Hibiscus esculentus L.) I - Pesquisas Básicas. Revista de Agricultura, v.29, p.239252, 1954.

HAMON, S.; CHARRIER, A.; KOECHLIN, J.; VANSLOTEN, D.H. Potential contribuitions to okra breeding thought the study of their genetics resources. In: INTERNATIONAL OKRA GENETIC RESOURCES WORKSHOP, Proceedings. New Delhi: NBPGR, 1990. p.77-88.

HANDERBURG, R.E.; WADATA, A.E.; WANG, C.Y. The commercial storange of fruits, vegetables and florist and nursery stocks. USDA, 1986. 130p.

INSTITUTO DE ECONOMIA AGRÍCOLA. COORDENADORIA DE ASSISTÊNCIA TÉCNICA INTEGRAL. Serv. Est. Agric., v.7, n.1, p.1742, 1996.

JESUS, R.M.; MENANDRO, M.S.; BATISTA, J.L.F.; COUTO, H.T. Efeito do tamanho do recipiente, tipo de substrato e sombreamento na produção de mudas de louro (Cordia trichotoma (Vell) Arrab.) e gonçalo-alves (Astronium fraxinifolium Schott). IPEF, n.37, p.13-19, 1987.

JORGE, J.A.; LOURENÇÃO, A.L.; ARANHA, C. (Ed.) Instruções agrícolas para o Estado de São Paulo. 5.ed. Campinas: Instituto Agronômico, 1990. 233p. (IAC. Boletim Técnico, 200).

KNAVEL, D.E. Influence of container, container size and spacing on growth of transplant and yields in tomato. Proceedings American Society Horticultural Science, v.86, p.583-586, 1965. 
LATIMER, J.G. Container size and shape influence growth and landscape performance of marigold seedling. HortScience, v.26, n.2, p.124-126, 1991.

LIPTAY, A.; EDWARDS, D. Tomato seedling growth in response to variation in root container shape. HortScience, v.29, n.6, p.633-635, 1994.

MARTINELLO, G.E.; ABBOUD, A.C.S.; LEAL, N.R. Análise em componentes principais e de agrupamentos aplicada a características morfológicas e agronômicas em quiabo. Horticultura Brasileira, v.14, n.2, p.200-203, 1996.

MEDINA, P.V.L. Efeito de profundidade de plantio, tipo de leito, modo de semeadura e pré-tratamento na germinação do quiabeiro (Hibiscus esculentus L.). Viçosa, 1971. 42p. Dissertação (M.S.) - Universidade Federal de Viçosa.

MINAMI, K. Produção de mudas de alta qualidade em horticultura. São Paulo: T. A. Queiroz, 1995. 128p.

MINAMI, K.; MODOLO, V.A; ZANIN, A.C.W.; TESSARIOLI NETO, J. Cultura do quiabeiro: técnicas simples para hortaliça resistente ao calor. Piracicaba: ESALQ, Divisão de Biblioteca e Documentação, 1997. 36p. (Série Produtor Rural, 3).

NICKLOW, C.W.; MINGES, P.A. Plant growing factors influencing the field performance of the Fireball tomato vatiety. Proc. Amer. Soc. Hort. Sci., v.81, p.443-450, 1963.

OLIVEIRA, R.P., SCIVITTARO, W.B.; VASCONCELLOS, L.A.B.C. Avaliação de mudas de maracujazeiro em função do substrato e do tipo de bandeja. Scientia Agrícola, v.50, n.2, p.261-266, 1993. 
PANTÁSTICO, E.R. Postharvest physiology, handling and utilization of tropical and subtropical fruits and vegetable. Westport: AVI, 1975. $559 p$.

PEDROSA, J.F. Caracterização de 100 introduções de quiabeiro (Abelmoschus esculentus (L.) Moench) do banco de germoplasmas de hortaliças da Universidade Federal de Viçosa (BGH-UFV). Viçosa, 1976. 43p. Dissertação (M.S.) - Universidade Federal de Viçosa.

PEDROSA, J.F.; MIZUBUTI, A.A.; CASALI, V.W.D.; CAMPOS, J.P. de Caracterização morfológica de introduções de quiabeiro (Abelmoschus esculentus (L.) Moench). Horticultura Brasileira, v.1, n.1, p.14-23, 1983.

PEREIRA, A.L.; PEREIRA, I.C.C.L.; FARIA, E.H.S.; PARRAGA, M.S. Avaliação de métodos de semeadura do quiabeiro (Abelmoschus esculentus (L.) Moench). In: XXXV CONGRESSO BRASILEIRO DE OLERICULTURA, Foz do Iguaçu, 1995. p.103. Resumos.

PIMENTEL, A.M.P. Olericultura no trópico úmido: hortaliças na Amazônia. São Paulo: Agronômica Ceres, 1985. 322p.

RUFF, M.; KRIZEK, D.; MIRECKI, R.; INOUYE, D. Restricted root zone volume: Influence on growth and development of tomato. Journal of American Society for Horticultural Science, v.112, n.5, p.763-769, 1987.

SAS INSTITUTE. SAS user's guide: statistics. 5.ed. Cary, 1985. 958p.

SEMENTES HORTEC. Catálogo de sementes de hortaliças. São Paulo, 1995. $47 p$.

SILVA JÚNIOR, A.A.; VISCONTI, A. Recipientes e substratos para a produção de mudas de tomate. Agropecuária Catarinense, v.4, n.4, p.20-23, 1991. 
SPURR, S.H.; BARNES, B.V. Ecologia florestal. México: AGT, 1982.

TAVEIRA, J.A.M. Produção de mudas. Curitiba: SENAR, 1996. p.66-86.

TESSARIOLI NETO, J. Recipientes, embalagens e acondicionamento de mudas de hortaliças, In: MINAMI, K. Produção de mudas de alta qualidade em horticultura. São Paulo: T. A. Queiroz, 1995. p.59-64.

VIDAL-TORRADO, P.; SPAROVEK, G. Mapa pedológico detalhado do Campus "Luiz de Queiroz", ESALQ/USP. Piracicaba: ESALQ, 1993 Escala 1:10.000.

VIEIRA, J.V. Efeitos de métodos de produção e idade de transplante de mudas no rendimento do repolho (Brassica oleracea var. capitata). Viçosa, 1977. 43p. Dissertação (M.S.) - Universidade Federal de Viçosa.

WESTON, L.A.; ZANDSTRA, B.H. Effect of root container size and location of production on growth and yield of tomato tranplants. Journal of the American Society for Horticultural Science., v.111, n.4, p.498-501, 1986. 